\title{
Extreme Air Pollution Events Spiking Ionic Levels at Urban and Rural Sites of Indo-Gangetic Plain
}

\author{
Manisha Mishra, U.C. Kulshrestha* \\ School of Environmental Sciences, Jawaharlal Nehru University, New Delhi 110067, India
}

\begin{abstract}
The present study is a modest attempt to quantify the water-soluble inorganic ions (WSIIs) in the early morning (fogforming) ambient air on the central Indo-Gangetic Plain (IGP) during winter via dissolution using a low-cost refluxing mist chamber. The chemical composition of the bulk samples showed significant differences in the WSIIs between the two monitored sites, one urban and the other rural, with $\mathrm{NH}_{4}{ }^{+}$(47\% and $37 \%$, respectively) and $\mathrm{Ca}^{2+}(18 \%$ and $8 \%$, respectively) being the major cations and $\mathrm{NO}_{3}{ }^{-}\left(10 \%\right.$ and $16 \%$, respectively) and $\mathrm{SO}_{4}{ }^{2-}$ (9\% and $14 \%$, respectively) being the major anions. The WSII concentration spiked during November at both locations ( $\sum$ WSII $=159.6$ and $141.9 \mu \mathrm{g} \mathrm{m}^{-3}$ ) due to two extreme air pollution events, viz., i) the burning of crop residue and ii) the Diwali festival. These changes, which were corroborated by observations of the meteorological conditions, played an essential role in the wintertime atmospheric chemistry. On foggy days, significant scavenging of ions associated with crustal dust $\left(\mathrm{Ca}^{2+}, \mathrm{Na}^{+}, \mathrm{Mg}^{2+}\right.$ and $\left.\mathrm{Cl}^{-}\right)$occurred, although the ambient concentrations of other species $\left(\mathrm{K}^{+}, \mathrm{NH}_{4}^{+}, \mathrm{NO}_{2}{ }^{-}, \mathrm{NO}_{3}{ }^{-}\right.$and $\left.\mathrm{SO}_{4}{ }^{2-}\right)$ remained relatively unaffected. Furthermore, the relationship between the cations and anions demonstrated that $\mathrm{NH}_{3}$ and $\mathrm{HONO}$, as the primary gaseous species, were involved in heterogeneous aqueous-phase reactions and the formation of secondary aerosols. Source apportionment based on principal component analysis and the mass ratios also indicated that local anthropogenic sources, in addition to natural ones such as soil/road dust and biogenic emissions, influenced the WSII composition. Vehicular exhaust, solid waste and biofuel burning were identified as the major contributors of WSIIs at the urban site, whereas biomass burning, agricultural activity and coal combustion in brick kilns were the predominant sources at the rural site.
\end{abstract}

Keywords: Atmospheric chemistry; Mist chamber; Ionic interactions; Fog scavenging; Source apportionment.

\section{INTRODUCTION}

The onset of winter season in the Indo-Gangetic Plain (IGP) region has been found to be associated with the formation of a thick blanket of brown clouds within two to three kilometers above the surface (Ramanathan et al., 2005; Chung and Ramanathan, 2006; Nakajima et al., 2007). This seasonal phenomenon is an outcome of the complex interplay between various meteorological and anthropogenic factors. The meteorological factors mainly include calm winds, lower mixing height, temperature inversion, etc. They restrict the dispersion of pollutants and leads to their accumulation in the lower atmosphere (Nair et al., 2007; Gautam, 2014; Pani and Verma, 2014; David et al., 2011; Sen et al., 2017). As to the anthropogenic factors, the increased emissions of harmful pollutants from residential, industrial and transport sectors to meet the energy demands of this densely populated region undermines air quality (Singh et al., 2014; Pan et al., 2015;

\footnotetext{
* Corresponding author.

E-mail address: umeshkulshrestha@gmail.com
}

Liu et al., 2018). Moving further, another vital connection between the deteriorating air quality and certain extraneous extreme pollution episodes such as stubble burning in the states falling upwind of the IGP and the use of firecrackers during the celebration of Diwali festival needs to be factored in while accounting for the overall atmospheric profile of the region during the winter season (Kulshrestha et al., 2004; Singh et al., 2010; Perrino et al., 2011; Jain et al., 2014; Singh and Kaskaoutis, 2014; Izhar et al., 2018). These cumulatively result in the reduction of visibility, poor air quality and jeopardizing of health indicators (Seaton et al., 1995; Gautam et al., 2007; Balakrishnan et al., 2019).

Furthermore, the winter season is characterized by higher moisture content in the form of fog which provides a potent medium for the chemical reactions of different atmospheric organic and inorganic species (Jain et al., 2000; Rajput et al., 2016; Tie et al., 2017; Bharali et al., 2019). As for the latter, significant concentrations of major inorganic ions have been reported in the non-precipitating clouds and fog (Jacob and Hoffmann, 1983; Jacob et al., 1984; Ram et al., 2012; Straub et al., 2012). Longer residence time and higher scavenging efficiency through aqueous-phase reactions explain the reason behind high concentrations of inorganic 
ions in the cloud and fog water (Jacob and Hoffmann, 1983; Fridlind and Jacobson, 2000). The ambient air chemical composition during winters is assumed to be determined by the following factors: (1) the composition of the activated cloud condensation nuclei $(\mathrm{CCN})$ on which the water droplet condenses, (2) the absorption of atmospheric gases at the droplet's surface, and (3) the subsequent aqueous-phase reactions of homogeneous and heterogeneous species. Such physical as well as chemical interactions among water droplets, gases and aerosols in the ambient air invariably alter the regional-scale atmospheric chemistry (Seinfeld and Pandis, 1998; Raes et al., 2000).

Previous studies conducted in IGP have extensively reported the concentration of ions either in fog water or in the aerosols and gases separately in the atmosphere, which provide vital information regarding the different kinds of phase chemistry during winter period (Kulshrestha et al., 2005; Kaul et al., 2011; Gupta and Mandariya, 2013; Agarwal et al., 2017; Ghude et al., 2017; Nath and Yadav, 2018; Rajput et al., 2018; Izhar et al., 2020). But there are certain interactions going on in the ambient air, particularly during winters owing to aqueous-phase chemistry, which simultaneously includes interactions of gases and aerosol with fog droplets (Waldman et al., 1982; Jacob et al., 1984). Furthermore, the presence of fog, on the one hand, scavenge the aerosols through their dissolution in large droplets and on the other hand also enhance the formation of secondary aerosols, which accentuates the need to look into the overall chemical composition of dominant atmospheric species (Lopez-Hilfiker et al., 2014; Rao and Vejerano, 2018). Ionic composition regulates atmospheric acidity, which helps us understand the partitioning of semi-volatile water-soluble compounds between particulates and gas phase. In such a scenario, the study of bulk air mass samples will be helpful in characterizing the water-soluble inorganic ionic (WSII) species and major reaction chemistry occurring during fog- forming hours in ambient air. The present study has following research objectives: (1) to quantify overall (bulk) concentrations of WSIIs and monthly variation at different land use sites during fog-forming hours in winters, (2) to assess the impact of fog scavenging and ionic interactions of different WSIIs in ambient air and (3) to identify major sources of WSIIs using principal component analysis (PCA) model at different sites of the IGP.

\section{METHODOLOGY}

\section{Sampling Sites}

IGP region is known for its very high population density and stationary sources of pollutant emissions in the environment. Keeping in view the different land use patterns, two sites have been selected: Prayagraj as an urban site and Madhupur, a village in Pratapgarh district of UP, as a rural site as shown in Fig. 1.

\section{Prayagraj (an Urban Site)}

Prayagraj $\left(25^{\circ} 54^{\prime} \mathrm{N}, 81^{\circ} 85^{\prime} \mathrm{E}\right)$, formerly known as Allahabad, is the administrative headquarters and among one of the most populous cities of Uttar Pradesh state. Located in the southern Uttar Pradesh, at the confluence of the Ganga and Yamuna, the city's area covers $70.5 \mathrm{~km}^{2}$ area. As per the census 2011, the district has a population density of 1,086 per $\mathrm{km}^{2}$. National Highway-130 passes through the city and attracts very high traffic density. Allahabad Development Authority (ADA) continuously focuses on the planning of the suburban areas of the city. As a result, in 2011, it was ranked the world's $130^{\text {th }}$ fastestgrowing city. Within the city, sampling was conducted in the Phaphamau area, located in the northern part of the city. The sampler was mounted at $1.5 \mathrm{~m}$ above the surface on the terrace of a residential building in a colony situated nearby the highway.

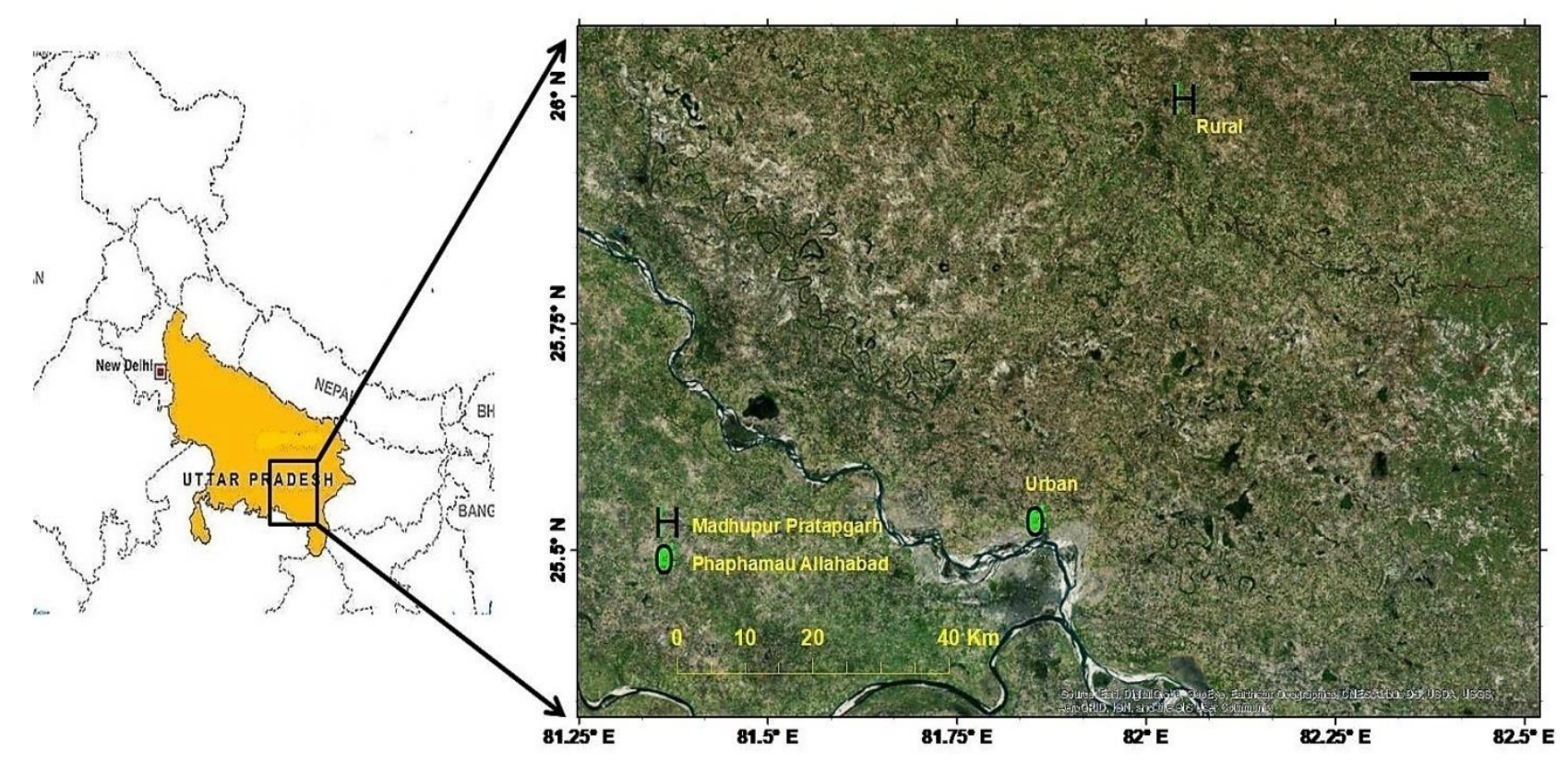

Fig. 1. Description of sampling sites. 


\section{Madhupur (a Rural Site)}

Madhupur village $\left(25^{\circ} 98^{\prime} \mathrm{N}, 82^{\circ} 04^{\prime} \mathrm{E}\right)$ were selected as rural site, which is in Pratapgarh, a district adjacent to the Prayagraj. Madhupur site is located $70 \mathrm{~km}$ away in the northeastern side of Prayagraj. Sai and the Ganges are the main rivers flowing through Pratapgarh district. As per the census 2011, the district has a population density of 854 per $\mathrm{km}^{2}$. The site comes under one of the most backward districts of India. Primarily an agrarian district, Pratapgarh has risen in ranks as the top producer of Aonla or Amla fruit, which is used as herbal medicine. The village is poorly developed as hardly any roads pass through the area with two brick kiln units within $5 \mathrm{~km}^{2}$ of the site. It has very low vehicle density and high vegetation cover. Biomass burning, soil resuspension, and agricultural activities are the main source of pollution in the area. Sampling was conducted on the terrace of a twofloored house. Similar to the urban site, the fog sampler was mounted approximately $1.5 \mathrm{~m}$ above the surface of the terrace.

\section{Sample Collection Using Mist Chamber}

Collection of ambient air bulk samples during winter months was carried out using customized low-cost refluxing mist chambers. Very similar mist chamber has been used by Jain et al. (1999). A schematic design of the glass mist chamber used in the current study has been shown in Fig. 2. The air inlet sucks the air directly into the mist-forming spherical glass chamber, filled with collecting solution. The spherical glass chamber has a capacity of $250 \mathrm{~mL}$ and it consists of an air inlet, a nebulizing nozzle, and a port for the addition and removal of the solution. The collecting solution (Milli-Q water) is drawn from the reservoir into the nozzle, where impaction with the incoming air forms a fine aqueous mist. The fine aqueous drops provide a large surface area for efficient extraction of water-soluble compounds from the air. The mist is drawn upward through the mist chamber where aqueous droplets containing scrubbed atmospheric species collide and are refluxed into the reservoir. The upper side of the mist chamber was designed with a few bends,

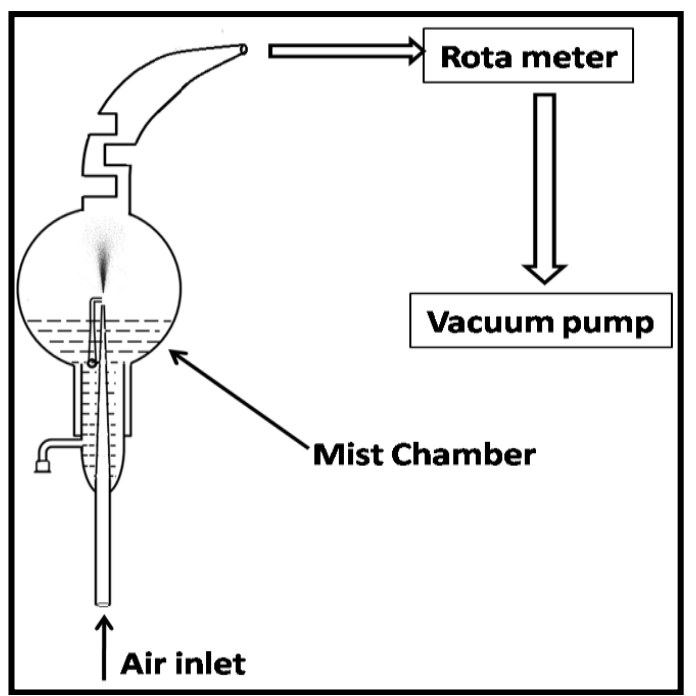

Fig. 2. Description of mist chamber used in collecting the bulk samples. which help to reduce the sample loss and evaporation of the solution. It was connected to the well-calibrated rotameter to maintain the flow rate, which was further connected to the vacuum pump through a silicon tube. Though the flow rate was maintained at $15 \mathrm{~L} \mathrm{~min}^{-1}$, the pressure drop at each stage was taken into the account (between 12 and $14 \mathrm{~L} \mathrm{~min}^{-1}$ ), which was corrected while data calculation and analysis.

The use of such type of mist chambers have been reported in various previous studies, which have shown a very high collection efficiency for gases (Stratton et al., 2001; Spaulding et al., 2002; François et al., 2005; Hennigan et al., 2018). More recently, as in the present study, the mist chambers have also been used for particle plus gas analysis (King and Weber, 2013). Here, the bulk samples which are collected through the incorporation of all the water-soluble components entering with the air stream into the mist drops and their subsequent dissolution in water represents the total concentration of a particular chemical species present in ambient air. The measurement of the collection efficiency of the sample collector was performed with the cations and anions analysis using ion chromatography. Two identical mist chambers were operated in a series similar to prior studies for characterizing their collection efficiency (Spaulding et al., 2002; Hennigan et al., 2018). Collection efficiency (CE) was calculated using the following formula:

\section{$C E=1-C 2 / C 1$}

where $\mathrm{C} 2$ and $\mathrm{C} 1$ are the concentrations of the analyte in first and second sampler. For most of the analyzed species, the collection efficiency was found to be very high (>95\%), which strengthened the robust nature of the method. Replicate samples were also collected at each site. The result showed a difference of about $12-18 \%$ for all the cations and anions, which is within acceptable limits. However, a slight variation in replicate samples can be attributed to the changing dynamics of analytes in the atmosphere.

Since the winter period, particularly morning hours, has been evident of very high relative humidity (RH), most of the soluble gaseous species also get dissolved onto the water droplets or more precisely on fog droplets and alters atmospheric chemistry, which is the primary reason to use mist chamber during winter months. Along with efficient scrubbing of aerosols, mist chamber also allows the gas- and aqueous-phase diffusion of analytes onto the mist droplets inside the glass chamber. Most of the studies which focus on fog chemical characterization use condensation method, which ultimately gives the species concentrations in per volume of fog (in $\mu$ eq $\mathrm{L}^{-1}$ ). However, the current study includes the overall concentration of measured chemical species in ambient air $\left(\mu \mathrm{g} \mathrm{m}^{-3}\right)$ during winters from November 2016 to February 2017. Considering the fog-forming hours in India, the sampling was conducted for $5 \mathrm{~h}$ from 03:00 to 08:00. About $60 \mathrm{~mL}$ of deionized Milli-Q water was used as collecting solution. Due to high RH, water loss through evaporation was very less and for most of the time it was less than $10 \mathrm{~mL}$, which was corrected before analysis. After the collection of samples, glass chamber was rinsed $(20 \mathrm{~mL}$ $\times 3$ ) every time carefully to eliminate contamination in 
samples through the detachable lower part. Total 41 and 22 samples were collected at urban and rural sites, respectively. Due to limited power supply in villages, sample size was less at the latter site. Samples were stored using thymol as a preservative and kept in a refrigerator at $-4^{\circ} \mathrm{C}$ to avoid any chemical alterations. Meteorological parameters were reported on a regular basis from online website wunderground.com. Wind speed, temperature and $\mathrm{RH}$ are primarily considered for the study.

\section{Analysis on Ion Chromatography}

Five major cations $\left(\mathrm{Na}^{+}, \mathrm{NH}_{4}^{+}, \mathrm{K}^{+}, \mathrm{Ca}^{2+}\right.$ and $\left.\mathrm{Mg}^{2+}\right)$ and four major anions $\left(\mathrm{Cl}^{-}, \mathrm{NO}_{2}{ }^{-}, \mathrm{NO}_{3}{ }^{-}\right.$and $\left.\mathrm{SO}_{4}{ }^{2-}\right)$ in the bulk samples were analyzed using ion chromatography (883 Basic IC Plus; Metrohm). Cation column (Metrosep A Supp 4, 250/4.0; Metrohm) was used for the determination of cations using a mixture of $1.7 \mathrm{mmol} \mathrm{L} \mathrm{L}^{-1} \mathrm{NaHCO}_{3}$ and $1.8 \mathrm{mmol} \mathrm{L}-1 \mathrm{Na}_{2} \mathrm{CO}_{3}$ as eluent. Whereas, anion column (Metrosep C4, 100/4.0; Metrohm) was used to determine anions using a mixture of $0.7 \mathrm{mmol} \mathrm{L}^{-1}$ dipicolinic acid and $1.7 \mathrm{mmol} \mathrm{L}^{-1}$ nitric acid as eluent. MERCK certified standards for anions and cations were used for the calibration. Four standards of 1, 2, 5 and $10 \mathrm{ppm}$ were used to draw the standard calibration curve for cations and anions. The correlation coefficient of standards was observed to be 0.99 . Calibration curve was plotted every time the new eluent is prepared and quality was ensured by repeating the analysis of standards on regular interval. Replicate sample analysis has shown a relative deviation within a range of $12-18 \%$. The detection limits (DLs) of $\mathrm{Cl}^{-}, \mathrm{NO}_{2}{ }^{-}, \mathrm{SO}_{4}{ }^{2-}, \mathrm{NO}_{3}{ }^{-}, \mathrm{Na}^{+}, \mathrm{NH}_{4}^{+}, \mathrm{K}^{+}, \mathrm{Ca}^{2+}$ and $\mathrm{Mg}^{2+}$ for our instrument were calculated as $0.03,0.75$, $0.24,1.13,0.35,0.29,0.63,0.85$ and $0.33 \mathrm{mg} \mathrm{mL}^{-1}$, respectively. For quality assurance and quality control (QA/QC), procedure field blanks were collected at the start of each month sampling. Blanks were handled and analyzed in the similar way as other samples. Most of the target ions were found below detection limits except $\mathrm{Cl}^{-}$which was subtracted/corrected at each step while calculations. The final concentration of ions was calculated using following formula:

$\mathrm{C}\left(\mu \mathrm{g} \mathrm{m}^{-3}\right)=\left[\mathrm{X}\left(\mu \mathrm{g} \mathrm{mL}^{-1}\right) \times \mathrm{Vs}(\mathrm{mL})\right] /\left[\mathrm{R}\left(\mathrm{m}^{3} \mathrm{~min}^{-1}\right) \times\right.$ $\mathrm{t}(\min )]$

where $\mathrm{X}$ is the concentration of particular ion obtained from $\mathrm{IC}, \mathrm{Vs}$ is the volume of sampling solution, $\mathrm{R}$ is the flow rate, $t$ is the duration of sampling and $\mathrm{C}$ is the final concentration of $\mathrm{X}$ ion in the ambient air.

\section{Ion Balance Check}

An ionic charge balance is usually performed in aerosols to check the data quality, where the sum of the equivalent ratios of cations and anions are assessed to fulfil the principal of electro-neutrality and characterizing the aerosol acidity (Pani et al., 2017). In the present study, the method does not include exclusively aerosols. The bulk concentration of WSIIs in fog-forming air mass simultaneously include fog droplets and diffused gases (mainly $\mathrm{NH}_{3}$ and $\mathrm{HONO}$ ) along with the aerosols and their collection in the sampling solution (Milli-Q water), not filters. The ion balance check revealed an excess cation case as reported by earlier studies in the Indian region (Kulshrestha et al., 2003). According to Kulshrestha et al. (2005) bicarbonate measurements substantially fill up the gap in the cation and anion difference in the Indian region. This is because much of the calcium which is a dominant cation is associated with $\mathrm{HCO}_{3}{ }^{-}$in the samples which is corroborated with the ion balance studies reported by Satyanarayana et al. (2010) and Kumar et al. (2016). In the present study we found the ratio of sum of equivalents of anion and cations $\left(\Sigma^{-} / \Sigma^{+}\right)$in the range of $0.08-0.33$ at the urban site and $0.12-0.47$ at the rural site (Table 1). The deficiency of unmeasured water-soluble organic anions (such as acetate and formate) might also have led to the lower ratio values, which have been reported to be present in abundance in the wintertime studies of IGP (Verma et al., 2017; Nath and Yadav, 2018). The importance of organic anions in charge balance has been also reported in previous studies (Kerminen et al., 2001; Lee et al., 2003). Furthermore, the lower ratios were identified due to $\mathrm{NH}_{4}{ }^{+}$-rich conditions owing to its efficient collection and higher solubility. In this context, Trebs et al. (2005) have also reported an excess in $\mathrm{NH}_{4}{ }^{+}$species due to greater diffusion of gaseous $\mathrm{NH}_{3}$, which might be neutralizing the other unmeasured anions in the atmosphere. The ratio of sum of cations other than $\mathrm{NH}_{4}{ }^{+}$and sum of anions was still observed to be in lower range $(0.51$ and 0.86 for urban and rural sites, respectively), which is probably due to excess in $\mathrm{Ca}^{2+}$ concentrations. However, the major limitation of such neutralization process is the unmeasured highly soluble bicarbonate ions formed through the dissolution of $\mathrm{CO}_{2}$ whose solubility depends on available cation species in the atmospheric samples. In this context higher concentration of unmeasured bicarbonate ions might be compensated with the excess of $\mathrm{NH}_{4}{ }^{+}$and $\mathrm{Ca}^{2+}$ ions. Additionally, such interactions with measured ions have been explained using scatter plots in the results.

\section{RESULTS AND DISCUSSION}

\section{Variations in pH Values of Samples over the Sites}

The $\mathrm{pH}$ values are one of the major indicators of dominant

Table 1. Ion balance for the major ions analyzed in the samples $\left(\mu\right.$ eq $\left.\mathrm{m}^{-3}\right)$.

\begin{tabular}{lll}
\hline \multirow{2}{*}{ Ions } & \multicolumn{2}{c}{$\mu$ eq ${ }^{-3}$} \\
\cline { 2 - 3 } & Urban & Rural \\
\hline $\mathrm{Na}^{+}$ & 0.31 & 0.12 \\
$\mathrm{NH}_{4}{ }^{+}$ & 3.23 & 2.84 \\
$\mathrm{~K}^{+}$ & 0.13 & 0.35 \\
$\mathrm{Ca}^{2+}$ & 1.09 & 0.34 \\
$\mathrm{Mg}^{2+}$ & 0.15 & 0.07 \\
$\mathrm{Cl}^{-}$ & 0.29 & 0.06 \\
$\mathrm{NO}_{2}^{-}$ & 0.06 & 0.02 \\
$\mathrm{NO}_{3}{ }^{-}$ & 0.23 & 0.19 \\
$\mathrm{SO}_{4}{ }^{2-}$ & 0.26 & 0.18 \\
$\sum^{-}$ & 4.91 & 3.75 \\
$\sum^{+}$ & 0.84 & 0.45 \\
$\sum^{-} / \sum^{+}$ & 0.18 & 0.25 \\
\hline
\end{tabular}


species governing the aqueous-phase reaction chemistry in the atmosphere (Wang et al., 2005; Morgan, 1982). The $\mathrm{pH}$ was analyzed to get the relative difference in the acidity of ambient air bulk samples (Fig. 3). The average $\mathrm{pH}$ of the collected urban samples was found to be $5.7 \pm 0.1$, which ranged from 5.1 to 6.2. Whereas, rural samples have shown a relatively lower average $\mathrm{pH}$ of $5.1 \pm 0.1$ ranging from 4.5 to 5.6. In the absence of effective neutralization, $\mathrm{pH}$ of rural samples indicates the higher concentrations of $\mathrm{H}^{+}$ions resulting in greater atmospheric acidity. However, higher $\mathrm{pH}$ of urban samples shows the efficient neutralization of acidic species in urban atmosphere which can be attributed to the presence of alkaline species from dust particles emitted from construction activities, deforestation, and road dust and soil resuspension (Kulshrestha and Sharma, 2015). The presence of gases like $\mathrm{CO}_{2}, \mathrm{SO}_{2}$ and $\mathrm{NO}_{2}$ also greatly affect the $\mathrm{pH}$ values, depending upon their concentration and dissolution properties in water (Lekouch et al., 2010).

\section{Relative Contribution of WSIIs}

The relative contribution of different analyzed WSIIs has been shown in Fig. 4. $\mathrm{NH}_{4}{ }^{+}$and $\mathrm{Ca}^{2+}$ were found as major cations and $\mathrm{NO}_{3}{ }^{-}$and $\mathrm{SO}_{4}{ }^{2-}$ as major anions at both the sites. $\mathrm{NH}_{4}{ }^{+}$contributed around $47 \%$ of analyzed WSIIs at the urban site and $37 \%$ at the rural site. $\mathrm{NH}_{4}{ }^{+}$has been reported to be dominating atmospheric species in fog water and wintertime aerosol studies (Ali et al., 2004; Nath and Yadav, 2018; Ge et al., 2019). Since animal/human excreta are one of the most important sources of $\mathrm{NH}_{3}$, densely populated IGP has been observed as one of the major hotspots of ammonia emission in the world (Galloway et al., 2004). Owing to higher solubility, $\mathrm{NH}_{4}{ }^{+}$readily gets scavenged by water droplets present in the air during humid conditions in winter mornings and reacts with the atmospheric acidic components such as chlorides, nitrates and sulfates (Waldman et al., 1982; Jacob and Hoffmann, 1983; Bongartz et al., 1995; Ge et al., 2019). Urban sources of $\mathrm{NH}_{3}$ include vehicular exhaust, open waste burning and human excreta/sludge degradation, whereas biomass burning, emissions from agriculture and livestock farming remain as major sources in the rural areas (Singh and Kulshrestha, 2014; Singh et al., 2014). At urban site $\mathrm{NH}_{4}{ }^{+}$was followed by $\mathrm{Ca}^{2+}>\mathrm{NO}_{3}{ }^{-}>$ $\mathrm{SO}_{4}{ }^{2-}>\mathrm{Cl}^{-}>\mathrm{Na}^{+}>\mathrm{K}^{+}>\mathrm{NO}_{2}^{-}>\mathrm{Mg}^{2+}$. However, at the rural site $\mathrm{NH}_{4}{ }^{+}$was followed by $\mathrm{NO}_{3}{ }^{-}>\mathrm{SO}_{4}{ }^{2-}>\mathrm{Ca}^{2+}>\mathrm{K}^{+}$ $>\mathrm{Na}^{+}>\mathrm{Cl}^{-}>\mathrm{Mg}^{2+}>\mathrm{NO}_{2}^{-}$. Ever-growing urbanization, migration and unplanned construction activities are continuously lowering the urban green cover which leads to very high erosion of surface dust and the main sources of $\mathrm{Ca}^{2+}$ in urban areas (Gupta et al., 2016). However, in rural areas, high green cover limits the emission of $\mathrm{Ca}^{2+}$ in the atmosphere (Tiwari et al., 2016; Mishra and Kulshrestha, 2017). Both $\mathrm{NO}_{3}{ }^{-}$and $\mathrm{SO}_{4}{ }^{2-}$ were found to be higher at the rural site as compared to urban site, which primarily can be attributed to the solid fuel burning in the form of wood, crop residues, dung cakes, domestic wastes or low-grade coal burning in the villages (Singh et al., 2014).

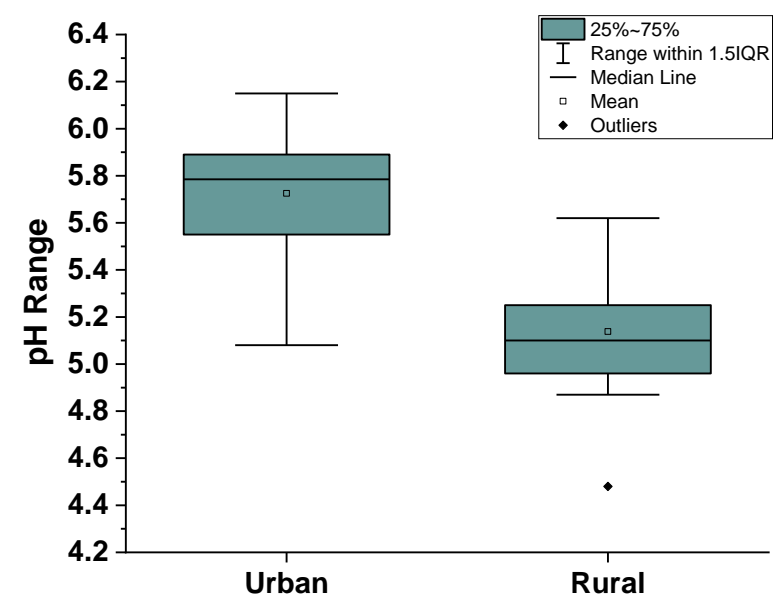

Fig. 3. The $\mathrm{pH}$ variation of bulk air samples at both the sites.
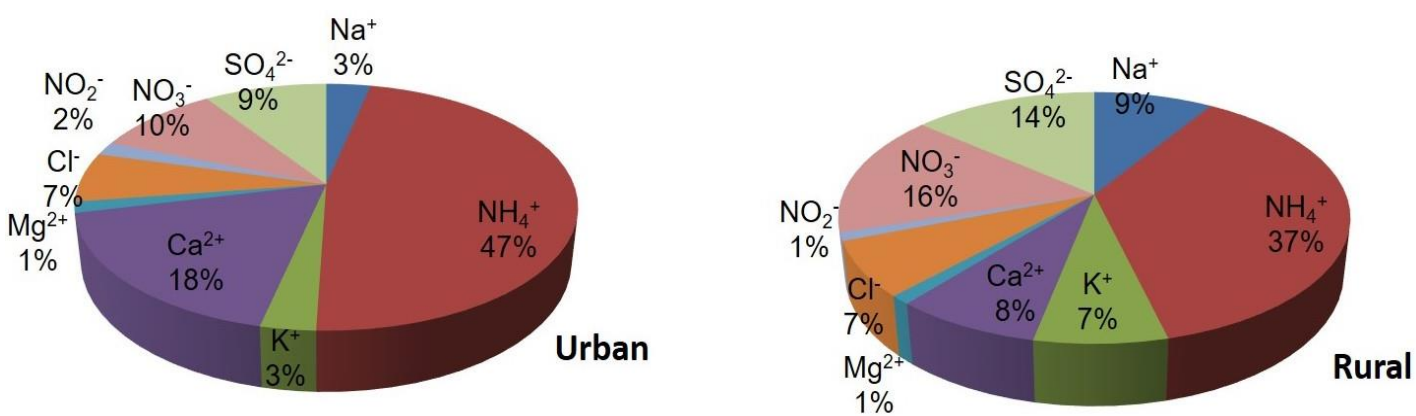

Fig. 4. Percentage contribution of measured ions at urban and rural sites. 


\section{Temporal Variation of WSIIs}

Since the study includes an overall characterization of WSIIs, i.e., without phase differentiation, here samples were not classified based on fog occurrence. The concentration of major WSIIs in ambient air bulk samples at urban and rural sites is given in Table 2 .

\section{Urban Site}

Temporal variation of measured cations and anions at the urban site is shown in Fig. 5. Being dominant species during winters, mean concentration of $\mathrm{NH}_{4}{ }^{+}$at urban site was 58.2 $\pm 17.5 \mu \mathrm{g} \mathrm{m}^{-3}$ ranging from a minimum $24.7 \mu \mathrm{g} \mathrm{m}^{-3}$ to a maximum $123.5 \mu \mathrm{g} \mathrm{m}^{-3}$. The IGP has been majorly reported as the hotspot of $\mathrm{NH}_{3}$ emission (Behera et al., 2013). Apart from natural sources, higher traffic density and vehicular exhausts are the potential sources of $\mathrm{NH}_{3}$ emission in urban areas. However, being one of the most soluble atmospheric gases, $\mathrm{NH}_{3}$ readily gets absorbed by fog droplets and get converted into $\mathrm{NH}_{4}{ }^{+}$(Jacob et al., 1984; Shi et al., 1999). It was followed by $\mathrm{Ca}^{2+}$ with an average concentration of 21.8 $\pm 7.1 \mu \mathrm{g} \mathrm{m}^{-3}$ ranging from a minimum $10.6 \mu \mathrm{g} \mathrm{m}^{-3}$ to a maximum $35.8 \mu \mathrm{g} \mathrm{m}^{-3}$. Construction activities and resuspended road dust are most important urban sources of $\mathrm{Ca}^{2+}$. Since $\mathrm{Ca}^{2+}$ concentration occurs higher in coarse mode and primarily in the form $\mathrm{CaCO}_{3}$, these large particulates provide a surface for the fog water accumulation. Due to the lower mixing height in winters, these particles remain suspended in the lower atmosphere and enhance the fog formation rate (Finlayson-Pitts and Pitts, 2000). Both $\mathrm{Ca}^{2+}$ and $\mathrm{NH}_{4}{ }^{+}$have been reported to be crucial for the neutralization of acidic species in the atmosphere (Khemani et al., 1987). $\mathrm{Na}^{+}, \mathrm{K}^{+}$and $\mathrm{Mg}^{2+}$ mean concentrations were $7.2 \pm 7.7 \mu \mathrm{g} \mathrm{m}^{-3}$, $5.1 \pm 3.6 \mu \mathrm{g} \mathrm{m}^{-3}$ and $1.8 \pm 0.7 \mu \mathrm{g} \mathrm{m}^{-3}$, respectively. $\mathrm{Na}^{+}$and $\mathrm{Mg}^{2+}$ mostly come from crustal sources, sea salts or longrange transport (LRT); however, $\mathrm{K}^{+}$could have natural (crustal) as well as anthropogenic (biomass burning) sources (Kumar et al., 2016).

Average $\mathrm{NO}_{3}{ }^{-}$and $\mathrm{SO}_{4}{ }^{2-}$ concentrations at the urban site were observed to be $14.4 \pm 6.8 \mu \mathrm{g} \mathrm{m}^{-3}$ and $12.6 \pm 6.3 \mu \mathrm{g} \mathrm{m}^{-3}$, respectively. $\mathrm{NO}_{3}{ }^{-}$and $\mathrm{SO}_{4}{ }^{2-}$ generally occur as secondary pollutants formed from their precursor gases $\mathrm{NO}, \mathrm{NO}_{2}$, volatile $\mathrm{HNO}_{3}$ and $\mathrm{SO}_{2}$. Prayagraj has a very high traffic density due to its large urban population where unregulated engines of local public transports such as Vikram tempo, buses and heavy-duty trucks, pass from nearby highways and emit enhanced amounts of these pollutants. During winters mixing height goes as low as $200 \mathrm{~m}$ and these exhaust emissions get accumulated in the lower atmosphere. Fog has been reported to intensify in the presence of precursor gases like $\mathrm{NO}_{2}$ and $\mathrm{SO}_{2}$ (Klemm and Lin, 2016). In aqueous phase,

Table 2. Concentration of various chemical constituents at urban and rural sites.

\begin{tabular}{|c|c|c|c|c|c|c|}
\hline & \multicolumn{3}{|c|}{ Urban $\left(\mathrm{n}=41 ;\right.$ in $\left.\mu \mathrm{g} \mathrm{m}^{-3}\right)$} & \multicolumn{3}{|c|}{ Rural $\left(\mathrm{n}=22 ;\right.$ in $\left.\mu \mathrm{g} \mathrm{m}^{-3}\right)$} \\
\hline & Mean \pm SD $(\sigma)$ & Median & Range & Mean \pm SD $(\sigma)$ & Median & Range \\
\hline $\mathrm{Na}^{+}$ & $7.2 \pm 7.7$ & 5.1 & $1.1-44.8$ & $6.6 \pm 6.7$ & 3.8 & $0.7-25.1$ \\
\hline $\mathrm{NH}_{4}^{+}$ & $58.2 \pm 17.5$ & 58.7 & $24.7-103.5$ & $38.3 \pm 13.1$ & 39.8 & $18.9-62.6$ \\
\hline $\mathrm{K}^{+}$ & $5.1 \pm 3.6$ & 4.1 & $1.9-21.6$ & $6.8 \pm 6.3$ & 4.4 & $0.6-27.9$ \\
\hline $\mathrm{Ca}^{2+}$ & $21.8 \pm 7.1$ & 20.5 & $10.6-35.8$ & $8.1 \pm 2.3$ & 7.6 & $5.1-14.6$ \\
\hline $\mathrm{Mg}^{2+}$ & $1.8 \pm 0.7$ & 1.7 & $0.7-4.3$ & $1.2 \pm 0.5$ & 1.0 & $0.7-3.2$ \\
\hline $\mathrm{Cl}^{-}$ & $10.4 \pm 7.4$ & 9.0 & $2.8-46.2$ & $6.4 \pm 5.4$ & 4.5 & $2.0-21.4$ \\
\hline $\mathrm{NO}_{2}^{-}$ & $2.5 \pm 1.4$ & 2.2 & $0.5-6.9$ & $1.1 \pm 0.5$ & 1.0 & $0.3-2.3$ \\
\hline $\mathrm{NO}_{3}^{-}$ & $14.4 \pm 6.8$ & 12.7 & $3.0-34.2$ & $16.4 \pm 7.6$ & 13.9 & $8.9-36.2$ \\
\hline $\mathrm{SO}_{4}^{2-}$ & $12.6 \pm 6.3$ & 11.4 & $4.2-30.3$ & $15.1 \pm 11.1$ & 10.9 & $4.7-50.2$ \\
\hline
\end{tabular}
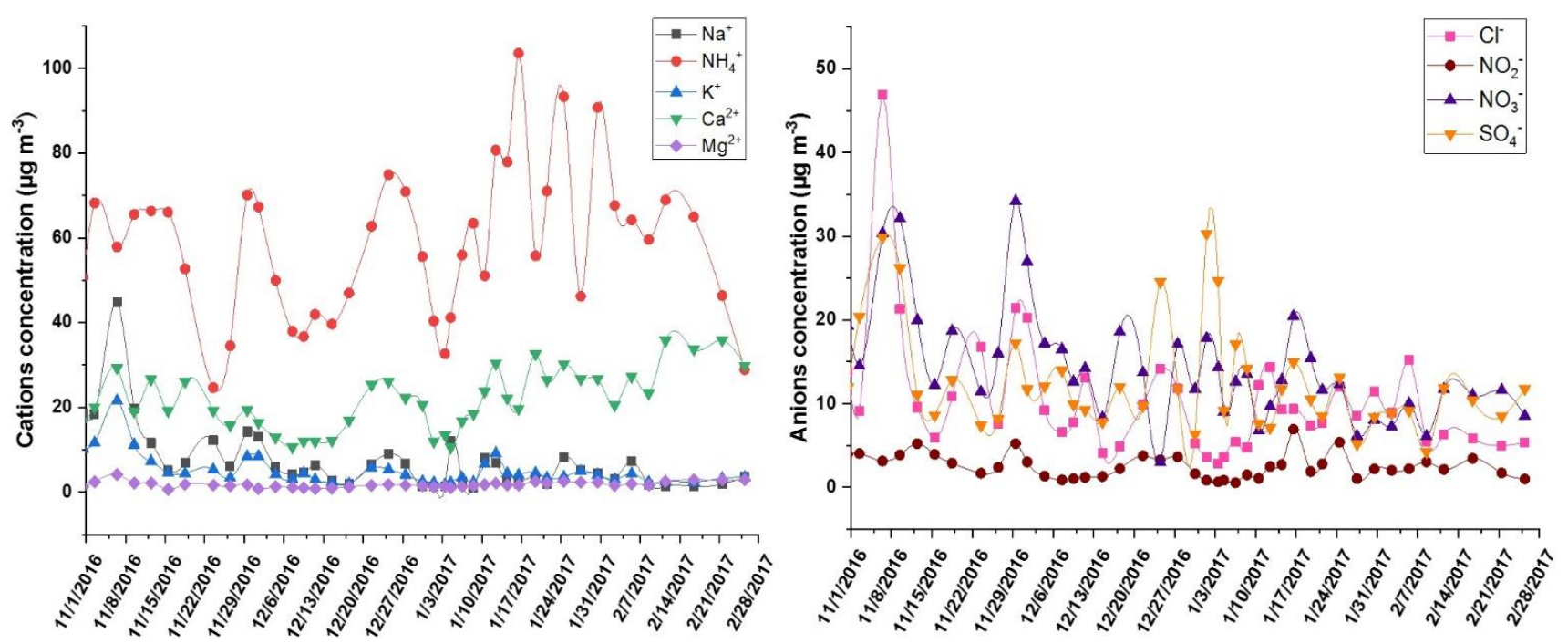

Fig. 5. Temporal variation of cations and anions at the urban site. 
$\mathrm{NO}_{2}$ and $\mathrm{SO}_{2}$ get dissolved in water droplets, where they oxidize into $\mathrm{HONO}, \mathrm{NO}_{2}{ }^{-}, \mathrm{NO}_{3}{ }^{-}$and $\mathrm{SO}_{4}{ }^{2-}$ respectively, by oxidizing species such as $\mathrm{OH}$ and $\mathrm{RH}$ radicals, $\mathrm{H}_{2} \mathrm{O}, \mathrm{O}_{3}$ and $\mathrm{O}_{2}$ (Seinfeld and Pandis, 1998; Finlayson-Pitts and Pitts, 2000). A higher concentration of HONO in early hours provides the biggest source for hydroxyl radicals, which convert gases into nitrous, nitric, sulfite and sulfuric acids.

$$
\begin{aligned}
& \mathrm{NH}_{3}+\mathrm{H}_{2} \mathrm{O} \longrightarrow \mathrm{NH}_{4}^{+}+\mathrm{OH}^{-} \\
& 2 \mathrm{NO}_{2}+\mathrm{H}_{2} \mathrm{O} \stackrel{\text { droplets }}{\longrightarrow} \mathrm{HONO}+\mathrm{HNO}_{3} \\
& \mathrm{HONO} \stackrel{\text { aqueous phase }}{\longrightarrow} \mathrm{H}^{+}+\mathrm{NO}_{2}^{-} \\
& \mathrm{NO}_{2}+\mathrm{O}_{3} \stackrel{\text { night hours }}{\longrightarrow} \mathrm{NO}_{3}+\mathrm{O}_{2} \\
& \mathrm{NO}_{3}+\mathrm{RH} \longrightarrow \mathrm{HNO}_{3}+\mathrm{R}^{\longrightarrow} \\
& \mathrm{OH}+\mathrm{SO}_{2} \stackrel{\text { metal }}{\longrightarrow} \mathrm{HOSO}_{2} \stackrel{\text { aqueous phase }\left(\mathrm{H}_{2} \mathrm{O}\right)}{\longrightarrow} \mathrm{H}_{2} \mathrm{SO}_{4}
\end{aligned}
$$

Such reactions in the presence of high moisture content and polluted atmosphere promote smog formation and cause thick-haze-like conditions and reduce visibility. $\mathrm{Cl}^{-}$ concentration was $10.4 \pm 7.4 \mu_{g ~ m^{-3}}$, which can be attributed to alkaline saline soil dust transported from upwind regions, $\mathrm{HCl}$ evaporation and municipal waste burning, which is very common for locals (Zhang et al., 2008' Perrino et al., 2011). Mean $\mathrm{NO}_{2}^{-}$concentration was found to be $2.5 \pm$ $1.4 \mu \mathrm{g} \mathrm{m}^{-3}$, which could be formed as a result of Eqs. (2) and (3) during morning hours and play as crucial interstitial oxidizing species (Finlayson-Pitts and Pitts, 2000).

\section{Rural Site}

Temporal variation of measured cations and anions at the rural site is shown in Fig. 6. $\mathrm{NH}_{4}{ }^{+}$was observed as the dominant species also at the rural site, having an average value of $38.3 \pm 13.1 \mu \mathrm{g} \mathrm{m}^{-3}$ with a minimum of $18.9 \mu \mathrm{g} \mathrm{m}^{-3}$ and maximum $62.6 \mu \mathrm{g} \mathrm{m}^{-3}$. Agricultural activities and livestock are the major sources of $\mathrm{NH}_{3}$ emission in rural areas (Singh and Kulshrestha, 2014). Madhupur village has agriculture practice, as their primary source of income. $\mathrm{NH}_{4}{ }^{+}$ was followed by $\mathrm{NO}_{3}{ }^{-}$and $\mathrm{SO}_{4}{ }^{2-}$ with an average concentration of $16.4 \pm 7.6$ and $15.1 \pm 11.1 \mu^{-3} \mathrm{~g} \mathrm{~m}^{-3}$, respectively. Despite having very few vehicles around the village, $\mathrm{NO}_{3}{ }^{-}$and $\mathrm{SO}_{4}{ }^{2-}$ concentrations were higher in rural samples. Biomass burning for cooking and heating purposes during winters in the villages of the IGP is a very common practice, which releases harmful primary pollutants $\mathrm{NO}_{2}$ and $\mathrm{SO}_{2}$ (Singh et al., 2014; Singh et al., 2016). In the absence of coal burning by local people, two operational units of brick kiln in the nearby area (in the range of $5 \mathrm{~km}^{2}$ ) were also observed as a significant source of $\mathrm{SO}_{2}$, which use low-grade coal as a fuel for the production. Since these precursor gases are highly hygroscopic, they quickly get incorporated into fog droplets. Also, they lead to the acidity in fog water samples in the absence of effective neutralization by alkaline species such as $\mathrm{NH}_{4}{ }^{+}$and $\mathrm{Ca}^{2+}$ (Reactions (1)-(6)). Furthermore, the $\mathrm{Ca}^{2+}$ concentration was found to be $8.1 \pm 0.5 \mu \mathrm{g} \mathrm{m}^{-3}$ which is about three times lower as compared to urban site and could be associated with the soil dust resuspension. Following these, the mean $\mathrm{K}^{+}$concentration was $6.8 \pm 6.3 \mu \mathrm{g} \mathrm{m}^{-3}$ and found to be significantly higher as compared to the urban site due to the prevalence of biomass burning in rural areas during winters (Kaneyasu et al., 1999). Average $\mathrm{Na}^{+}$concentration was found to be $6.6 \pm 6.7 \mu \mathrm{g} \mathrm{m}^{-3}$ and followed by $\mathrm{Cl}^{-}$ concentration with an average of $6.4 \pm 5.4 \mu \mathrm{g} \mathrm{m}^{-3}$. Alkaline saline soil dust have been reported to be the primary source of $\mathrm{Na}^{+}$and $\mathrm{Cl}^{-}$over IGP owing to the prevalence of continental air masses from northwestern regions (Ghosh et al., 2014). $\mathrm{Mg}^{2+}$ and $\mathrm{NO}_{2}{ }^{-}$were also found in a significant amount with average values of $1.2 \pm 0.5$ and $1.1 \pm 0.5 \mu \mathrm{g} \mathrm{m}^{-3}$, respectively.

\section{Meteorological Impact and Monthly Variation}

Changing meteorological conditions affect dilution and diffusion, as well as the accumulation and elimination of the
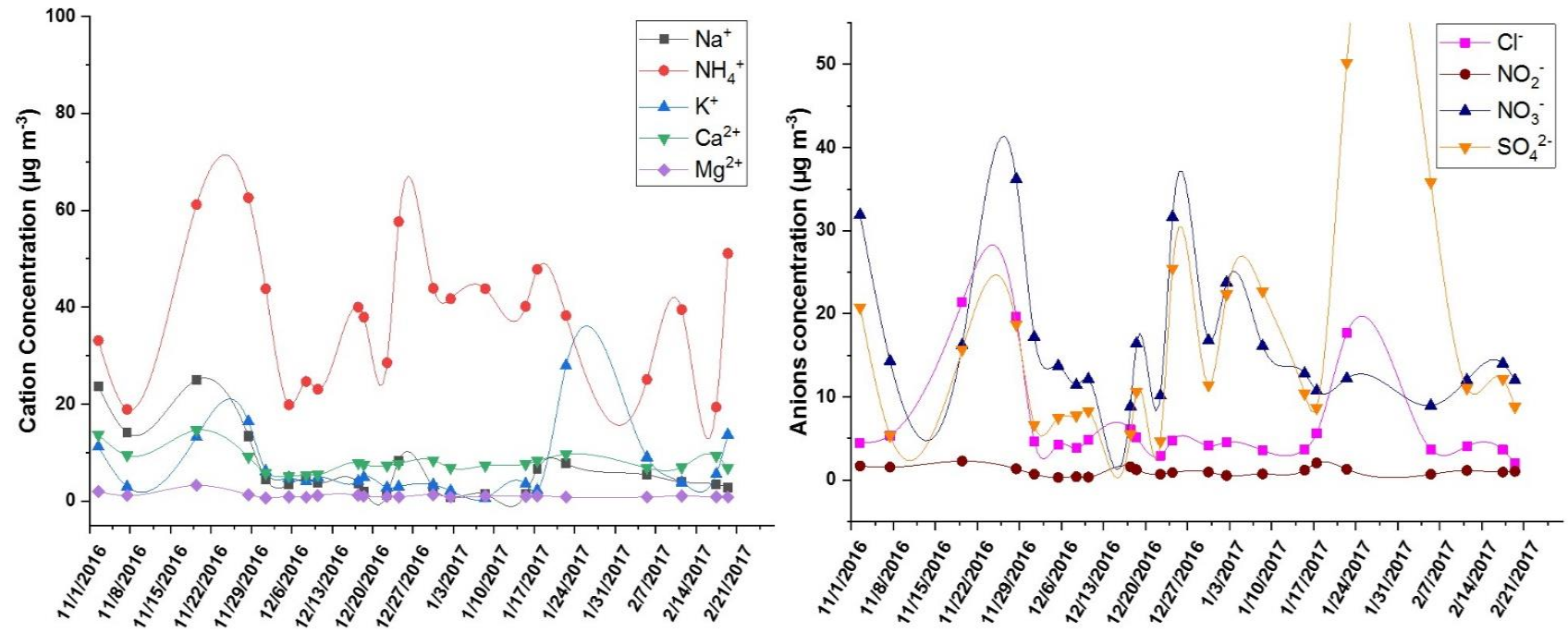

Fig. 6. Temporal variation of cations and anions at the rural site. 
air pollutants in the lower atmosphere (Wang et al., 2014; Xu et al., 2018). Pollutants get concentrated in humid and stagnant weather conditions, which are predominant in winters over IGP. Since major properties of atmospheric components are linked to their solubility in water and $\mathrm{NH}_{3}$ is reported to be highly soluble in increased $\mathrm{RH}$ conditions, $\mathrm{NH}_{4}{ }^{+}$was found as the dominant species in the collected bulk samples which varied widely in each month at both the sites (Fig. 7). Despite higher RH at the rural site as compared to urban site in each winter month (Table 3), its concentration remained higher at urban site in all the four months which suggests additional biogenic emissions of $\mathrm{NH}_{3}$ from the municipal sludge and sewage waste from the urban regions. However, its concentration is recorded to be highest in January at both the sites which can be corroborated with the high RH, relatively lower temperature and shallow boundary layer in the month of January. Most of the other ions varied widely in each month and did not show any common pattern. Additionally, the mass ratio of $\left(\mathrm{NO}_{2}{ }^{-}+\mathrm{NO}_{3}{ }^{-}\right) / \mathrm{SO}_{4}{ }^{2-}$ have shown an average value of 1.5 for both the sites and observed to have similar monthly trend (Nov. > Dec. > Feb. > Jan.) as shown in Table 3. This has suggested towards higher emission from stationary sources during January month for both the sites. But on an average November month samples have shown higher concentration of $\sum$ WSII with a spike in combustion-generated ions at both the sites (Table 3), which suggests that firecrackers pollution during Diwali festival and crop residue burning incidents in that period have a significant impact on the atmospheric composition of WSIIs. The five days' air mass backward trajectories (plotted
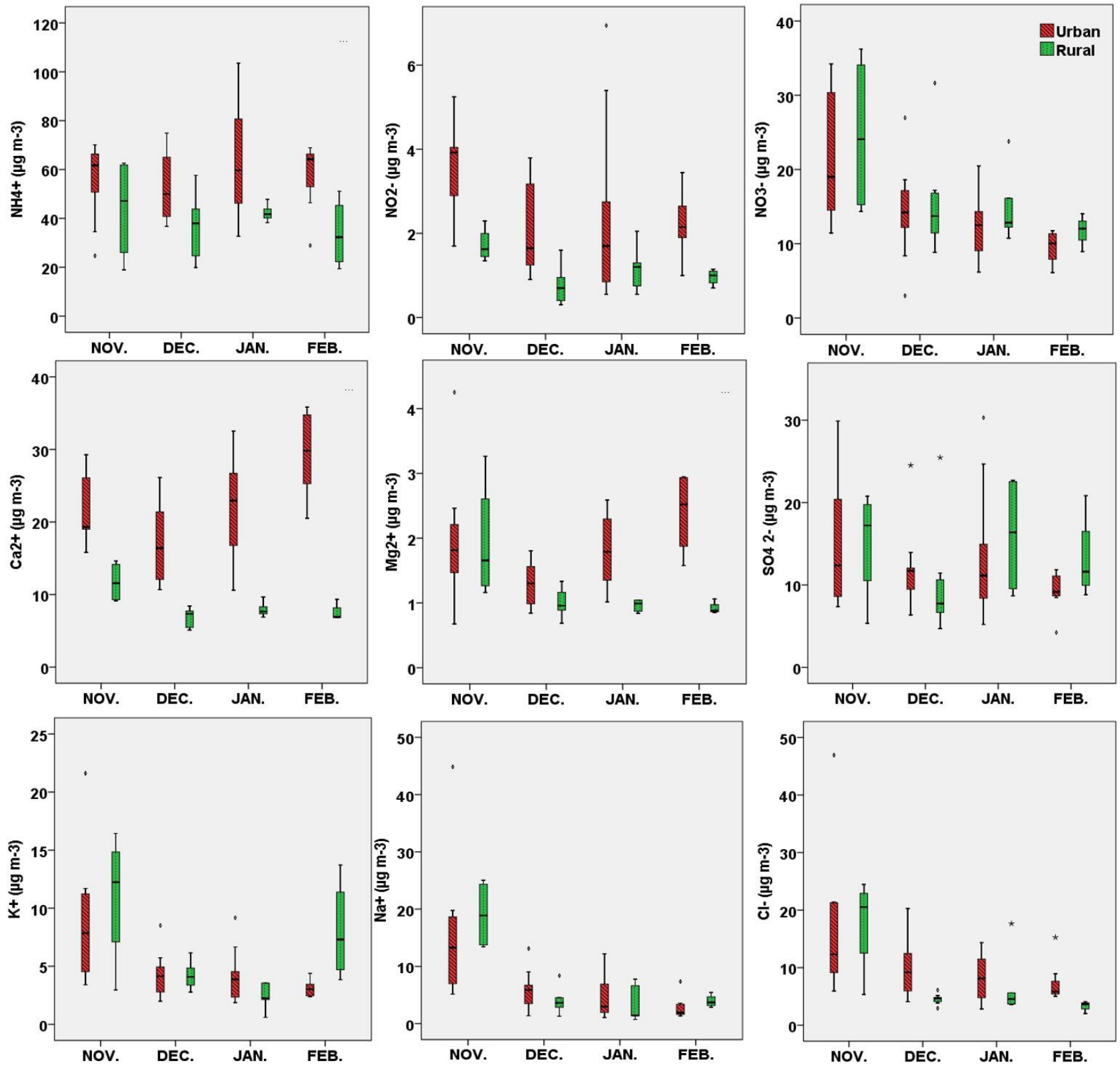

Fig. 7. Monthly variation of analyzed ions. Box plots indicate the $25-27^{\text {th }}$ percentiles and bars indicate the maximum and minimum value along with center line showing median value. Star is denoting the outlier value of the fluxes. 
Table 3. Mean temperature, relative humidity $(\mathrm{RH})$ and total WSIIs at two sites during winter months.

\begin{tabular}{|c|c|c|c|c|c|c|c|c|}
\hline & \multicolumn{2}{|c|}{ Temperature $\left({ }^{\circ} \mathrm{C}\right)$} & \multicolumn{2}{|c|}{ RH $(\%)$} & \multicolumn{2}{|c|}{$\sum$ WSII } & \multicolumn{2}{|c|}{$\left(\mathrm{NO}_{2}{ }^{-}+\mathrm{NO}_{3}{ }^{-}\right) / \mathrm{SO}_{4}{ }^{2-}$} \\
\hline & Urban & Rural & Urban & Rural & Urban & Rural & Urban & Rural \\
\hline 16 November & 21 & 21 & 55 & 63 & 159.6 & 141.9 & 1.7 & 1.9 \\
\hline 16 December & 17 & 16 & 69 & 85 & 119.5 & 81.7 & 1.6 & 1.8 \\
\hline 17 January & 16 & 15 & 71 & 79 & 132.5 & 108.4 & 1.2 & 0.9 \\
\hline 17 February & 21 & 19 & 52 & 63 & 123.5 & 87.2 & 1.4 & 1.1 \\
\hline
\end{tabular}

using the Hybrid Single-Particle Lagrangian Integrated Trajectory [HYSPLIT] model) of sampling duration, classified on a monthly basis, have also been traced to the upwind regions of the sampling sites particularly dominated from northwestern part at both the sites (Fig. 8). The northwestern region of IGP is known for the large-scale crop residue burning in November month which could also be contributing to the higher concentrations of WSII (Jain et al., 2014; Singh and Kaskaoutis, 2014). Monthly comparison of major inorganic ions (Fig. 7) clearly shows that most of the ions were higher at the urban site as compared to the rural site in all the four months except $\mathrm{K}^{+}, \mathrm{NO}_{3}{ }^{-}$and $\mathrm{SO}_{4}{ }^{2-}$ which is primarily due to plant-based combustion sources at the rural site.

\section{Fog Scavenging Using Statistical Analysis}

In order to understand the impact of fog occurrence on ambient concentrations of WSII suspended in the atmosphere, the sample data were classified into foggy days and nonfoggy days to perform a paired $t$-test. Due to unavailability of visibility data, foggy days were assumed as the days with more than $80 \% \mathrm{RH}$ and a temperature less than $20^{\circ} \mathrm{C}$ combined with visible documentation fog occurrence. High $\mathrm{RH}$ values during foggy days promote the wet scavenging of aerosols and gases and subsequently, their deposition in the form of dewdrops (Nath and Yadav, 2018). Result of paired $t$-test at a $95 \%$ significance level at urban and rural site is shown in Table 4. The ambient concentrations of $\mathrm{NH}_{4}{ }^{+}, \mathrm{NO}_{2}{ }^{-}, \mathrm{NO}_{3}{ }^{-}$and $\mathrm{SO}_{4}{ }^{2-}$ were not affected by fog occurrence at both the sites, suggesting their presence in the form of aerosols or suspended as fog droplets. This can also be attributed to the semi-volatile nature of these ions. However, concentrations of $\mathrm{Ca}^{2+}$ and $\mathrm{Na}^{+}$were found to be

Five Days BackwardTrajectories during winter season at Prayagraj

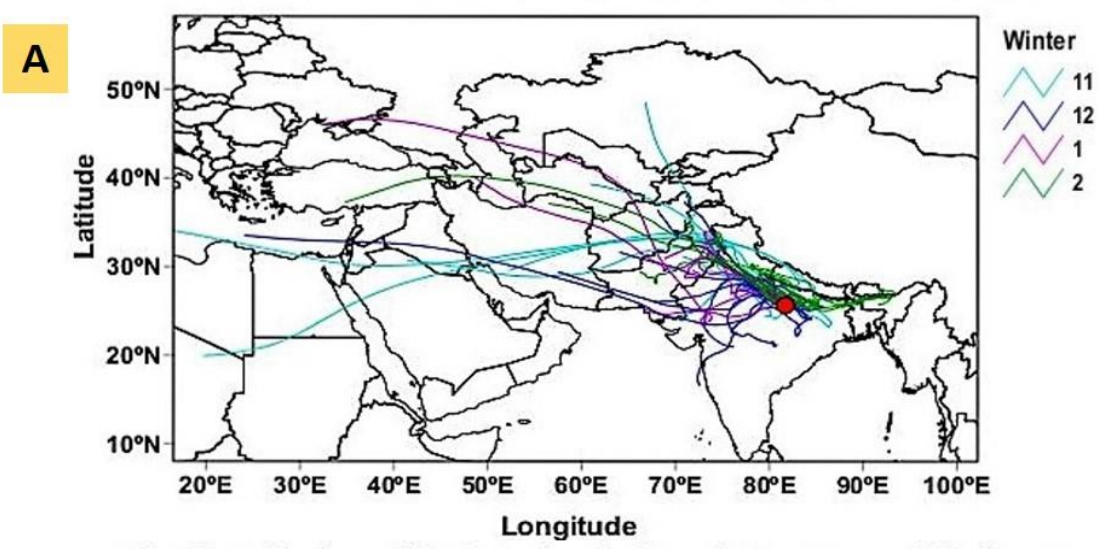

Five Days Backward Trajectories during winter season at Madhupur

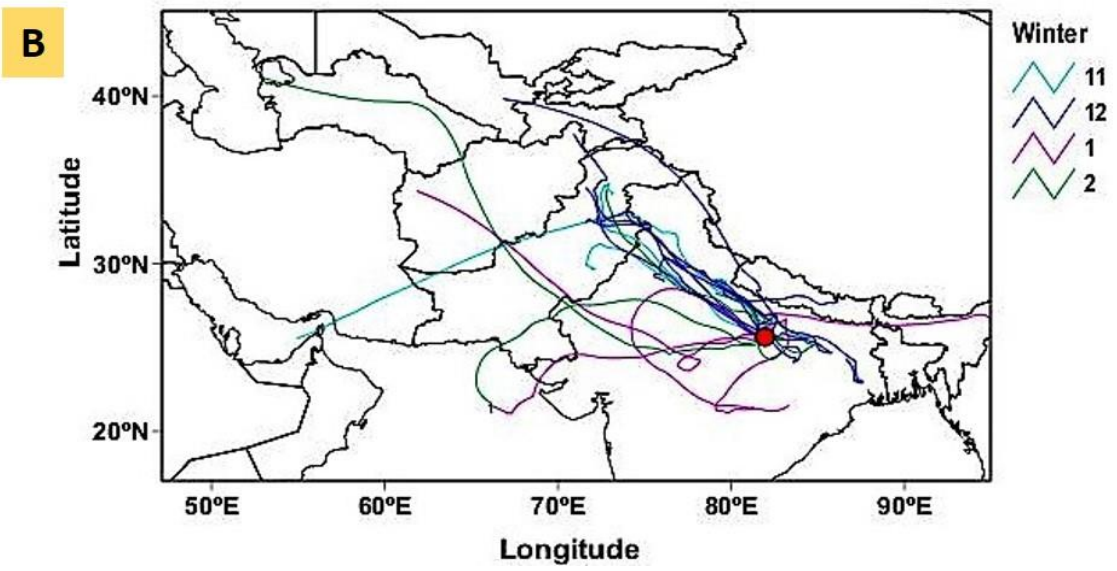

Fig. 8. Five days' backward air mass trajectories (HYSPLIT) at (A) urban and (B) rural sites (11 November, 12 December, 1 January and 2 February). 
Table 4. Details of paired $t$-test, performed to identify the significant difference (at $p=0.05$ ) in fog and non-fog days at each site.

\begin{tabular}{lll}
\hline \multirow{2}{*}{ WSII } & \multicolumn{2}{c}{ p-value } \\
\cline { 2 - 3 } & Urban & Rural \\
\hline $\mathrm{Na}^{+}$ & $0.04^{*}$ & $0.03^{*}$ \\
$\mathrm{NH}_{4}{ }^{+}$ & 0.88 & 0.63 \\
$\mathrm{~K}^{+}$ & $0.05^{*}$ & 0.07 \\
$\mathrm{Ca}^{2+}$ & $0.00^{*}$ & $0.05^{*}$ \\
$\mathrm{Mg}^{2+}$ & $0.00^{*}$ & 0.19 \\
$\mathrm{Cl}^{-}$ & 0.13 & $0.02^{*}$ \\
$\mathrm{NO}_{2}^{-}$ & 0.07 & 0.08 \\
$\mathrm{NO}_{3}^{-}$ & 0.48 & 0.50 \\
$\mathrm{SO}_{4}{ }^{2-}$ & 0.62 & 0.18 \\
\hline
\end{tabular}

significantly different on foggy and non-foggy days at both the sites, showing greater scavenging by fog droplets and deposition in the form of dewdrops. A significant difference of $\mathrm{K}^{+}$and $\mathrm{Mg}^{2+}$ on foggy days at urban site suggests its association with $\mathrm{Ca}^{2+}$ in the form of alkaline dust. Unlike urban site, the concentrations of $\mathrm{Mg}^{2+}$ and $\mathrm{K}^{+}$were not altered based on fog occurrence at the rural site owing to its continuous emission during sampling period. $\mathrm{Cl}^{-}$was found to be effectively scavenged during foggy days at the rural site but was not affected at the urban site, which can be attributed to its stable sources at the latter site.

\section{Winter Chemistry of WSIIs}

In order to investigate the major interactions of WSIIs occurring in the atmosphere, correlation coefficients (Table 5) along with the scatter plots (Figs. S1 and S2) were analyzed between each of the major cation with major anions.

\section{Urban Site}

Table 5 (Fig. S1) represents the relation of each anion with each of the cations at urban site. Despite being highest in concentration, $\mathrm{NH}_{4}{ }^{+}$showed least correlation with $\mathrm{SO}_{4}{ }^{2-}$, $\mathrm{Cl}^{-}$and $\mathrm{NO}_{3}{ }^{-}(\mathrm{r}=0.04,0.20$ and 0.09 , respectively), which are the most important component of secondary aerosols; however, it showed a good correlation $(\mathrm{r}=0.71$ at $p=0.01)$ with $\mathrm{NO}_{2}^{-}$. This can be attributed to the possible heterogeneous gaseous reaction of $\mathrm{HONO}$ with $\mathrm{NH}_{3}$ onto the fog droplets, which lead to the formation of $\mathrm{NH}_{4}{ }^{+}$and $\mathrm{NO}_{2}{ }^{-}$as an end product. HONO has a maximum concentration in morning hours before sunrise during winters which also affects the stoichiometry of atmospheric aqueous-phase reactions (Finlayson-Pitts and Pitts, 2000). However, a good correlation between them is suggestive of their common emission sources in urban areas such as vehicular emission or incorporation of diffused gases into mist during the sampling process. Furthermore, the anions were found to be poorly correlated with $\mathrm{Ca}^{2+}$ and slightly positive with $\mathrm{NO}_{2}^{-}(\mathrm{r}=0.27)$, showing its limited presence as a secondary aerosol. Rather, it could be directly emitted from excessive road construction activities in the city along with other crustal elements. $\mathrm{Ca}^{2+}$ might also act as a surface for fog formation because of its higher solubility in the humid environment. $\mathrm{K}^{+}$and $\mathrm{Na}^{+}$have shown a strong correlation with $\mathrm{Cl}^{-}(\mathrm{r}=0.87$ and 0.88 , respectively at $p=0.01$ ) and a good correlation with $\mathrm{NO}_{3}{ }^{-}$ ( $\mathrm{r}=0.56$ and 0.56 , respectively at $p=0.05$ ), which is indicating towards their presence in the form of secondary aerosols as $\mathrm{KCl}, \mathrm{KNO}_{3}, \mathrm{NaCl}$ and $\mathrm{NaNO}_{3} . \mathrm{SO}_{4}{ }^{2-}$ was also positively correlated with $\mathrm{Na}^{+}(\mathrm{r}=0.46)$ and $\mathrm{K}^{+}(\mathrm{r}=0.44$ at $p=0.05$ ), which suggests that they might act as primary alkaline species in the atmosphere for acid neutralization in urban samples.

\section{Rural Site}

Table 5 (Fig. S2) represents the relation of major anions with each cation at the rural site. $\mathrm{Na}^{+}$has shown a strong positive correlation with $\mathrm{Cl}^{-}(\mathrm{r}=0.60$ at $p=0.01)$, which shows the influence of alkaline saline soil dust or in the form of secondary salts as $\mathrm{NaCl}$ in the ambient air during sampling hours at rural site. $\mathrm{Na}^{+}$has also shown a strong correlation with $\mathrm{NO}_{2}^{-}(\mathrm{r}=0.66$ at $p=0.01)$, which implies to the formation of $\mathrm{NaNO}_{2}$. Being dominant inorganic ion in the rural samples, $\mathrm{NH}_{4}{ }^{+}$has shown a good correlation with the $\mathrm{NO}_{2}{ }^{-}, \mathrm{NO}_{3}{ }^{-}$and $\mathrm{Cl}^{-}(\mathrm{r}=0.46,0.48$ and 0.51 , respectively at $p=0.05$ ) suggesting efficient neutralization of acidity and the formation of secondary aerosols, viz. $\mathrm{NH}_{4} \mathrm{NO}_{2}$ and $\mathrm{NH}_{4} \mathrm{NO}_{3}$. However, it was least correlated with $\mathrm{SO}_{4}{ }^{2-}(\mathrm{r}=0.17) . \mathrm{SO}_{4}{ }^{2-}$ has shown a strong correlation with $\mathrm{K}^{+}(\mathrm{r}=0.63$ at $p=0.01)$, which suggests their common sources and strongly indicating towards biomass burning in rural areas. Furthermore, the good correlation of $\mathrm{K}^{+}$with $\mathrm{Cl}^{-}$

Table 5. Correlation matrix representing r-value between the cations and anions of both the sites.

\begin{tabular}{|c|c|c|c|c|c|c|c|c|c|c|}
\hline & & $\mathrm{Na}^{+}$ & $\mathrm{NH}_{4}{ }^{+}$ & $\mathrm{K}^{+}$ & $\mathrm{Ca}^{2+}$ & $\mathrm{Mg}^{2+}$ & $\mathrm{Cl}^{-}$ & $\mathrm{NO}_{2}^{-}$ & $\mathrm{NO}_{3}{ }^{-}$ & $\mathrm{SO}_{4}^{2-}$ \\
\hline & & \multicolumn{9}{|c|}{ Rural } \\
\hline $\mathrm{Na}^{+}$ & & & 0.27 & 0.42 & $0.85^{* *}$ & $0.80 * *$ & $0.60 * *$ & $0.66 * *$ & $0.47 *$ & 0.17 \\
\hline $\mathrm{NH}_{4}^{+}$ & & 0.03 & & 0.26 & 0.32 & 0.37 & $0.51 *$ & $0.46 *$ & $0.48 *$ & 0.17 \\
\hline $\mathrm{K}^{+}$ & & $0.93 * *$ & 0.17 & & 0.42 & 0.23 & $0.71 * *$ & 0.29 & 0.16 & $0.63 * *$ \\
\hline $\mathrm{Ca}^{2+}$ & $\approx$ & 0.03 & $0.41 *$ & 0.16 & & $0.82 * *$ & $0.57 * *$ & $0.80 * *$ & 0.36 & 0.25 \\
\hline $\mathrm{Mg}^{2+}$ & ?ְ & $0.41 *$ & 0.25 & $0.48^{*}$ & $0.81 * *$ & & $0.59 * *$ & $0.66 * *$ & 0.23 & -0.18 \\
\hline $\mathrm{Cl}^{-}$ & $\square$ & $0.88 * *$ & 0.20 & $0.87 * *$ & 0.17 & $0.45^{*}$ & & $0.52 *$ & 0.30 & 0.40 \\
\hline $\mathrm{NO}_{2}^{-}$ & & 0.30 & $0.71 * *$ & 0.36 & 0.27 & 0.23 & 0.32 & & 0.12 & 0.03 \\
\hline $\mathrm{NO}_{3}^{-}$ & & $0.56^{*}$ & 0.09 & $0.56^{*}$ & -0.19 & 0.08 & $0.58 *$ & $0.43^{*}$ & & 0.23 \\
\hline $\mathrm{SO}_{4}{ }^{2-}$ & & $0.46^{*}$ & 0.04 & $0.44 *$ & -0.15 & 0.20 & 0.39 & 0.12 & $0.51 *$ & \\
\hline
\end{tabular}

** Significant correlation at $\mathrm{p}=0.01$ level.

* Significant correlation at $\mathrm{p}=0.05$ level. 
$(\mathrm{r}=0.71$ at $p=0.01)$ suggests that the waste burning could be taking place for heating or cooking purposes during winters. $\mathrm{Ca}^{2+}$ and $\mathrm{Mg}^{2+}$ have shown highest correlation with $\mathrm{NO}_{2}^{-}(\mathrm{r}=0.80$ and 0.66 at $p=0.01$, respectively) as compared to other anions which suggest that crustal components might be providing active sites for nitrogenous gases oxidation.

\section{Source Apportionment}

Factor analysis is a statistical method, based on a mathematical model of the reduced factor analytical solution, to find small number of factors from a dataset of many correlated variables which explains a major part of the result thereby extracting latent information. To analyze factors, the original data matrix gets decomposed into the number of factor loading and a matrix of factor scores along with variance of dataset, i.e., analytical uncertainties. SPSS version 20.0 for Windows was used to analyze the principle components for each site. PCA was performed in order to determine the factors underlying the inter-correlations between the measured species, having a factor loading more than 0.5. In accordance with this, the grouping of ions in each factor was attributed to physical, chemical, meteorological reasons as well as to the common sources.

\section{Urban Site}

PCA of WSIIs at urban site $(n=41$; Table 6) identified four principle factors, which explains data loading for $91 \%$ (cumulative variance) where most of the components have significant loading, i.e., more than 0.5 values. The first factor explains about $45 \%$ of dataset, with the major loading of $\mathrm{Na}^{+}, \mathrm{K}^{+}, \mathrm{Mg}^{2+}, \mathrm{Cl}^{-}, \mathrm{NO}_{3}{ }^{-}$and $\mathrm{SO}_{4}{ }^{2-}$. This suggests the common emissions of $\mathrm{K}^{+}, \mathrm{Cl}^{-}, \mathrm{NO}_{3}{ }^{-}$and $\mathrm{SO}_{4}{ }^{2-}$ from municipal solid waste and biomass burning during winters as the dominant sources at urban site which are responsible for about half of the ambient levels of WSIIs. Such attributions can be further corroborated with the higher ratios of $\mathrm{Cl}^{-} / \mathrm{K}^{+}$(2.2) for municipal waste burning and $\mathrm{SO}_{4}{ }^{2-}$ $/ \mathrm{K}^{+}$(3.3) for biomass burning (Fourtziou et al., 2017). The presence of $\mathrm{Na}^{+}$and $\mathrm{Mg}^{2+}$ in Factor-1 is indicating towards their existence in the form of $\mathrm{NaCl}$ and $\mathrm{MgCl}_{2}$ salts. Second factor explains about $23 \%$ of dataset with a heavy loading of $\mathrm{Ca}^{2+}$ and $\mathrm{NH}_{4}^{+}$and light loading of $\mathrm{Mg}^{2+}$ and $\mathrm{NO}_{2}^{-}$. This suggests the oxidization of gases like $\mathrm{NH}_{3}$ and $\mathrm{NO}_{2}$ into $\mathrm{NH}_{4}{ }^{+}$and $\mathrm{NO}_{2}^{-}$on the dust particles, which is providing a surface for heterogeneous aqueous-phase interactions. $\mathrm{NH}_{3}$ sources in urban areas mainly include biogenic emission from sewage microbial degradation (Jain et al., 2000; Tiwari et al., 2012; Behera et al., 2013). Furthermore, the mean ratio of $\mathrm{Mg}^{2+} / \mathrm{Ca}^{2+}(0.08)$ has shown to have a crustal origin following the previously reported winter season ratio by $\mathrm{Mu}$ et al. (2019). Third factor explains $15 \%$ of dataset and primarily loaded with $\mathrm{NO}_{2}^{-}$and $\mathrm{NH}_{4}{ }^{+}$which indicates their common gaseous emission from vehicular exhausts. Fourth factor included only $\mathrm{SO}_{4}{ }^{2-}$ and explains $8 \%$ of the dataset which suggests the $\mathrm{SO}_{2}$ sources around the sampling sites. Coal burning in local food dhabas (restaurants) and heavyduty (diesel) vehicles are the primary sources of $\mathrm{SO}_{2}$ in urban areas. Vehicular emission of $\mathrm{SO}_{4}{ }^{2-}$ was further supported by the lower mean ratio (1.2) of $\mathrm{NO}_{3}{ }^{-} / \mathrm{SO}_{4}{ }^{2-}$ (Rajput, 2018). PCA clearly indicates that primary sources at urban sites are solid waste burning, biomass burning, soil dust, vehicular exhausts and biogenic emissions.

\section{Rural Site}

PCA of WSIIs at the rural site $(n=22$; Table 7$)$ identified three principal factors, which explains data loading for $80 \%$ cumulative variance where each factor has a variable loading more than 0.5 values. The first factor explains about more than half of the total variance, i.e., $51 \%$ with a high loading of $\mathrm{Na}^{+}, \mathrm{Ca}^{2+}, \mathrm{Mg}^{2+}, \mathrm{Cl}^{-}$and $\mathrm{NO}_{2}^{-}$which suggests the influence of natural sources like crustal dust and salts including dominant oxidation processes induced by HONO as a primary factor during early hours in winters. However, a higher ratio of $\mathrm{Mg}^{2+} / \mathrm{Ca}^{2+}(0.14)$ as compared to the urban site is indicating towards additional plant-based sources of $\mathrm{Mg}^{2+}$. The dominance of $\mathrm{K}^{+}$and $\mathrm{SO}_{4}{ }^{2-}$ in the second factor explains about $17 \%$ of the dataset, which is clearly indicating towards the biomass burning sources used for cooking and heating purposes in winters in rural areas. However, the brick kiln units have also been observed as an additional source of $\mathrm{SO}_{2}$, since none of the other coal-burning sources were observed in the area. Furthermore, the lower mean ratio of $\mathrm{Cl}^{-} / \mathrm{K}^{+}$(1.3) due to increased levels of $\mathrm{K}^{+}$and a higher ratio of $\mathrm{SO}_{4}^{2-} / \mathrm{K}^{+}$(4.4) due to increased concentration

Table 6. PCA results of urban site.

\begin{tabular}{|c|c|c|c|c|}
\hline Components & Factor-1 & Factor-2 & Factor-3 & Factor-4 \\
\hline $\mathrm{Na}^{+}$ & 0.884 & -0.288 & -0.190 & -0.212 \\
\hline $\mathrm{NH}_{4}^{+}$ & 0.364 & 0.619 & 0.584 & 0.052 \\
\hline $\mathrm{K}^{+}$ & 0.920 & -0.150 & -0.152 & -0.187 \\
\hline $\mathrm{Ca}^{2+}$ & 0.291 & 0.862 & -0.327 & 0.090 \\
\hline $\mathrm{Mg}^{2+}$ & 0.591 & 0.555 & -0.493 & 0.211 \\
\hline $\mathrm{Cl}^{-}$ & 0.897 & -0.137 & -0.139 & -0.231 \\
\hline $\mathrm{NO}_{2}^{-}$ & 0.460 & 0.377 & 0.654 & -0.074 \\
\hline $\mathrm{NO}_{3}^{-}$ & 0.677 & -0.415 & 0.327 & 0.078 \\
\hline $\mathrm{SO}_{4}^{2-}$ & 0.542 & -0.403 & 0.035 & 0.711 \\
\hline$\%$ of variance & 45 & 23 & 15 & 8 \\
\hline \multirow[t]{2}{*}{$\%$ cumulative } & 45 & 68 & 83 & 91 \\
\hline & $\begin{array}{l}\text { Solid waste and } \\
\text { biomass burning }\end{array}$ & $\begin{array}{l}\text { Road dust, biogenic } \\
\mathrm{NH}_{3}\end{array}$ & $\begin{array}{l}\text { Vehicular exhaust } \\
\text { gases }\end{array}$ & Coal burning \\
\hline
\end{tabular}


Table 7. PCA results of rural site.

\begin{tabular}{llll}
\hline Components & Factor-1 & Factor- 2 & Factor-3 \\
\hline $\mathrm{Na}^{+}$ & $\mathbf{0 . 8 7 4}$ & -0.219 & -0.069 \\
$\mathrm{NH}_{4}{ }^{+}$ & 0.473 & 0.087 & $\mathbf{0 . 6 8 7}$ \\
$\mathrm{K}^{+}$ & $\mathbf{0 . 5 1 5}$ & $\mathbf{0 . 7 2 7}$ & -0.303 \\
$\mathrm{Ca}^{2+}$ & $\mathbf{0 . 8 9 6}$ & -0.229 & -0.150 \\
$\mathrm{Mg}^{2+}$ & $\mathbf{0 . 8 0 8}$ & -0.433 & -0.102 \\
$\mathrm{Cl}^{-}$ & $\mathbf{0 . 8 2 2}$ & 0.176 & -0.086 \\
$\mathrm{NO}_{2}{ }^{-}$ & $\mathbf{0 . 7 7 4}$ & -0.364 & -0.148 \\
$\mathrm{NO}_{3}$ & 0.479 & 0.149 & $\mathbf{0 . 7 4 4}$ \\
$\mathrm{SO}_{4}^{2-}$ & -0.166 & $\mathbf{0 . 8 0 5}$ & 0.320 \\
$\%$ of variance & 51 & 17 & 12 \\
$\%$ cumulative & 51 & 68 & 80 \\
& Soil dust, gaseous HONO & Biomass burning, brick kilns & Agriculture emissions, $\mathrm{NH}_{4} \mathrm{NO}_{3}$ \\
\hline
\end{tabular}

of $\mathrm{SO}_{4}{ }^{2-}$ ions cumulatively indicated towards biomass and coal burning as their primary sources (Mu et al., 2019). Third factor dominated with $\mathrm{NH}_{4}{ }^{+}$and $\mathrm{NO}_{3}{ }^{-}$explains $12 \%$ of the dataset. This can be attributed to their common sources such as agriculture activities, gasoline vehicles and secondary aerosol formation as $\mathrm{NH}_{4} \mathrm{NO}_{3}$. Summing up, the PCA at rural site have shown that biomass burning, soil dust, coal combustion in brick kilns, agricultural emission (livestock and fertilizers) and light-duty vehicles as primary sources.

\section{Overview of Research Conducted and Implications}

Atmospheric abundance of WSIIs has been assessed from an urban (Prayagraj) and a rural location (Madhupur) in Indo-Gangetic Plain. The study has identified the sources of contamination in fog water. The urban site was highly influenced by the emissions of automobiles, solid waste and biofuel combustion while the rural site was influenced by biomass burning, agricultural activities and brick kilns. The crustal sources also contributed significantly. The study suggests to develop the regulations for pollution control accordingly. The levels of sulfates and nitrates in fog water give an idea about their role in visibility reduction during foggy days. The knowledge of gas-to-particle transformation can partially be utilized in understanding the scavenging of cloud condensation nuclei in the region.

\section{CONCLUSIONS}

This study investigated the interactions of the major water-soluble inorganic ions (WSIIs) in the early morning ambient air during winter and their principal causative factors at an urban and a rural site on the IGP. We found significantly high concentrations of cations and anions at both of the sites, largely owing to the higher humidity during wintertime and consequent aqueous-phase chemistry, which played a crucial role in the scavenging of pollutants and resulted in the rapid condensation and evaporation of water droplets on preexisting particles during the morning/foggy period. Compared to the urban site, the rural site displayed higher ambient concentrations of acidic species, which were primarily responsible for the lower $\mathrm{pH}$ at this location. In general, $\mathrm{NH}_{4}{ }^{+}, \mathrm{Ca}^{2+}, \mathrm{NO}_{3}{ }^{-}$and $\mathrm{SO}_{4}{ }^{2+}$, as the dominant ionic species, clearly governed the ambient chemistry of the
WSIIs. Furthermore, the higher mean concentration of $\sum$ WSII during November (based on the collected samples) indicated that extreme pollution episodes arising from festivities and crop residue burning in this month may have altered the atmospheric ionic composition. Fog scavenging significantly influenced the levels of the dust-associated components but did not affect the other species (e.g., $\mathrm{K}^{+}$, $\mathrm{NH}_{4}{ }^{+}, \mathrm{NO}_{2}{ }^{-}, \mathrm{NO}_{3}{ }^{-}$and $\mathrm{SO}_{4}{ }^{2-}$ ). Natural sources of WSIIs, such as crustal dust and biogenic emissions, were apparent at both sites. However, fossil fuel combustion, and solid waste and biofuel burning were the major anthropogenic contributors at the urban site, whereas biomass burning, brick kiln combustion and agricultural activity were the predominant ones at the rural site. The increased pollution, which is emitted by various sources, and the occasional spike in pollutant concentrations on the IGP is a serious concern in terms of both human health and regional ecosystems.

\section{ACKNOWLEDGMENT}

We sincerely thank the financial support received through CSIR (SRF) and DST-PURSE. We thank CIF, SES for providing analytical help during this research work. This work has been part of DRSNet-India network of Prof. U. C. Kulshrestha group.

\section{SUPPLEMENTARY MATERIAL}

Supplementary data associated with this article can be found in the online version at http://www.aaqr.org.

\section{REFERENCES}

Agarwal, A., Satsangi, A., Lakhani, A., Mangal, A. and Kumari, K.M. (2017). Characterization, sources and health risk analysis of $\mathrm{PM}_{2.5}$ bound metals during foggy and non-foggy days in sub-urban atmosphere of Agra. Atmos. Res. 197: 121-131. https://doi.org/10.1016/j.atmo sres.2017.06.027

Ali, K., Momin, G.A., Tiwari, S., Safai, P.D., Chate, D.M. and Rao, P.S.P. (2004). Fog and precipitation chemistry at Delhi, North India. Atmos. Environ. 38: 4215-4222. https://doi.org/10.1016/j.atmosenv.2004.02.055 
Balakrishnan, K., Dey, S., Gupta, T., Dhaliwal, R.S., Brauer, M., Cohen, A.J., Stanaway, J.D., Beig, G., Joshi, T.K., Aggarwal, A.N., Sabde, Y., Sadhu, H., Frostad, J., Causey, K., Godwin, W., Shukla, D.K., Kumar, G.A., Varghese, C.M., Muraleedharan, P., ... Dandona, L. (2019) The impact of air pollution on deaths, disease burden, and life expectancy across the states of India: The Global Burden of Disease Study 2017. Lancet Planet. Health 3: E26-E39. https://doi.org/10.1016/S2542-5196 (18)30261-4

Behera, S.N., Sharma, M., Aneja, V.P. and Balasubramanian, R. (2013). Ammonia in the atmosphere: A review on emission sources, atmospheric chemistry and deposition on terrestrial bodies. Environ. Sci. Pollut. Res. 20: 80928131. https://doi.org/10.1007/s11356-013-2051-9

Bharali, C., Nair, V.S., Chutia, L. and Babu, S.S. (2019). Modeling of the effects of wintertime aerosols on boundary layer properties over the Indo Gangetic Plain. J. Geophys. Res. 124: 4141-4157. https://doi.org/10.102 9/2018JD029758

Bongartz, A., Schweighoefer, S., Roose, C. and Schurath, U. (1995). The mass accommodation coefficient of ammonia on water. J. Atmos. Chem. 20: 35-58. https://doi.org/10.1007/BF01099917

Chung, C.E. and Ramanathan, V. (2006). Weakening of north Indian SST gradients and the monsoon rainfall in India and the Sahel. J. Clim. 19: 2036-2045. https://doi.o rg/10.1175/JCLI3820.1

David, L.M., Girach, I.A. and Nair, P.R. (2011). Distribution of ozone and its precursors over Bay of Bengal during winter 2009: Role of meteorology. Ann. Geophys. 29: 1613-1627. https://doi.org/10.5194/angeo29-1613-2011

Finlayson-Pitts, B.J. and Pitts, J.N. (2000). Photochemistry of important atmospheric species. In Chemistry of the upper and lower atmosphere, Elsevier, pp. 86-129. https://doi.org/10.1016/B978-012257060-5/50006-X

Fourtziou, L., Liakakou, E., Stavroulas, I., Theodosi, C., Zarmpas, P., Psiloglou, B., Sciare, J., Maggos, T., Bairachtari, K., Bougiatioti, A., Gerasopoulos, E., SardaEstève, R., Bonnaire, N. and Mihalopoulos, N. (2017). Multi-tracer approach to characterize domestic wood burning in Athens (Greece) during wintertime. Atmos. Environ. 148: 89-101. https://doi.org/10.1016/j.atmosen v.2016.10.011

François, S., Perraud, V., Pflieger, M., Monod, A. and Wortham, H. (2005). Comparative study of glass tube and mist chamber sampling techniques for the analysis of gaseous carbonyl compounds. Atmos. Environ. 39: 66426653. https://doi.org/10.1016/j.atmosenv.2005.07.041

Fridlind, A.M. and Jacobson, M.Z. (2000). A study of gasaerosol equilibrium and aerosol $\mathrm{pH}$ in the remote marine boundary layer during the First Aerosol Characterization Experiment (ACE 1). J. Geophys. Res. 105: 1732517340. https://doi.org/10.1029/2000JD900209

Galloway, J.N., Dentener, F.J., Capone, D.G., Boyer, E.W., Howarth, R.W., Seitzinger, S.P., Asner, G.P., Cleveland, C.C., Green, P.A., Holland, E.A., Karl, D.M., Michaels, A.F., Porter, J.H., Townsend, A.R. and Vörösmarty, C.J.
(2004). Nitrogen cycles: Past, present, and future. Biogeochemistry 70: 153-226. https://doi.org/10.1007/s1 0533-004-0370-0

Gautam, R., Hsu, N.C., Kafatos, M. and Tsay, S.C. (2007). Influences of winter haze on fog/low cloud over the IndoGangetic plains. J. Geophys. Res. 112: D05207. https://doi.org/10.1029/2005JD007036

Gautam, R. (2014). Challenges in early warning of the persistent and widespread winter fog over the IndoGangetic Plains: A satellite perspective. In Reducing disaster: Early warning systems for climate change, Springer Netherlands, pp. 51-61. https://doi.org/10.1007 1978-94-017-8598-3_3

Ge, B., Xu, X., Ma, Z., Pan, X., Wang, Z., Lin, W., Ouyang, B., Xu, D., Lee, J., Zheng, M., Ji, D., Sun, Y., Dong, H., Squires, F.A., Fu, P. and Wang, Z. (2019). Role of Ammonia on the feedback between AWC and inorganic aerosol formation during heavy pollution in the North China Plain. Earth Space Sci. 6: 1675-1693. https://doi.org/10.1 029/2019EA000799

Ghosh, S., Gupta, T., Rastogi, N., Gaur, A., Misra, A., Tripathi, S.N., Paul, D., Tare, V., Prakash, O., Bhattu, D., Dwivedi, A.K., Kaul, D.S., Dalai, R. and Mishra, S.K. (2014). Chemical characterization of summertime dust events at Kanpur: Insight into the sources and level of mixing with anthropogenic emissions. Aerosol Air Qual. Res. 14: 879-891. https://doi.org/10.4209/aaqr.2013.07.0240

Ghude, S.D., Bhat, G.S., Prabhakaran, T., Jenamani, R.K., Chate, D.M., Safai, P.D., Karipot, A.K., Konwar, M., Pithani, P., Sinha, V., Rao, P.S.P., Dixit, S.A., Tiwari, S., Todekar, K., Varpe, S., Srivastava, A.K., Bisht, D.S., Murugavel, P., Ali, K., ... Rajeevan, M. (2017).Winter fog experiment over the Indo-Gangetic plains of India. Curr. Sci. 112: 767-784. http://dx.doi.org/10.18520/cs/v 112/i04/767-784

Gupta, T. and Mandariya, A. (2013). Sources of submicron aerosol during fog-dominated wintertime at Kanpur. Environ. Sci. Pollut. Res. 20: 5615-5629. https://doi.org/ 10.1007/s11356-013-1580-6

Hennigan, C.J., El-Sayed, M.M.H. and Hodzic, A. (2018). Technical note: Detailed characterization of a mist chamber for the collection of water-soluble organic gases. Atmos. Environ. 188: 12-17. https://doi.org/10.1016/j.at mosenv.2018.06.019

Izhar, S., Rajput, P. and Gupta, T. (2018). Variation of particle number and mass concentration and associated mass deposition during Diwali festival. Urban Clim. 24: 1027-1036. https://doi.org/10.1016/j.uclim.2017.12.005

Izhar, S., Gupta, T. and Panday, A.K. (2020). Scavenging efficiency of water soluble inorganic and organic aerosols by fog droplets in the Indo Gangetic Plain. Atmos. Res. 235: 104767. https://doi.org/10.1016/j.atmosres.2019.10 4767

Jacob, D.J. and Hoffmann, M.R. (1983). A dynamic model for the production of $\mathrm{H}^{+}, \mathrm{NO}_{3}{ }^{-}$, and $\mathrm{SO}_{4}{ }^{2-}$ in urban fog. $J$. Geophys. Res. 88: 6611-6621. https://doi.org/10.1029/JC $088 \mathrm{iC} 11 \mathrm{p} 06611$

Jacob, D.J., Waldman, J.M., Munger, J.W. and Hoffmann, M.R. (1984). A field investigation of physical and 
chemical mechanisms affecting pollutant concentrations in fog droplets. Tellus B. 36: 272-285. https://doi.org/10. 3402/tellusb.v36i4.14909

Jain, M., Kulshrestha, U.C., Sarkar, A.K., Parashar, D.C. and Kumar, A. (1999). Measurements of formic and acetic acid levels in vapour phase at urban and semi-urban sites of Delhi. Indian J. Radio Space Phys. 28: 240-243.

Jain, M., Kulshrestha, U.C., Sarkar, A.K. and Parashar, D.C. (2000). Influence of crustal aerosols on wet deposition at urban and rural sites in India. Atmos. Environ. 34: 51295137. https://doi.org/10.1016/S1352-2310(00)00350-2

Jain, N., Bhatia, A. and Pathak, H. (2014). Emission of air pollutants from crop residue burning in India. Aerosol Air Qual. Res. 14: 422-430. https://doi.org/10.4209/aaqr.20 13.01 .0031

Kaneyasu, N., Yoshikado, H., Mizuno, T., Sakamoto, K. and Soufuku, M. (1999). Chemical forms and sources of extremely high nitrate and chloride in winter aerosol pollution in the Kanto Plain of Japan. Atmos. Environ. 33: 1745-1756. https://doi.org/10.1016/S1352-2310(98)003 96-3

Kaul, D.S., Gupta, T., Tripathi, S.N., Tare, V. and Collett, J.L. (2011). Secondary organic aerosol: A comparison between foggy and nonfoggy days. Environ. Sci. Technol. 45: 7307-7313. https://doi.org/10.1021/es201081d

Kerminen, V.M., Hillamo, R., Teinilä, K., Pakkanen, T., Allegrini, I. and Sparapani, R. (2001). Ion balances of size-resolved tropospheric aerosol samples: Implications for the acidity and atmospheric processing of aerosols. Atmos. Environ. 35: 5255-5265. https://doi.org/10.1016/ S1352-2310(01)00345-4

Khemani, L.T., Momin, G.A., Prakasa Rao, P.S., Safai, P.D. and Prakash, P. (1987). Influence of alkaline particulates on the chemistry of fog water at Delhi, North India. Water Air Soil Pollut. 34: 183-189. https://doi.org/10.1007/BF 00184759

King, L.E. and Weber, R.J. (2013). Development and testing of an online method to measure ambient fine particulate reactive oxygen species (ROS) based on the 2',7'dichlorofluorescin (DCFH) assay. Atmos. Meas. Tech. 6: 1647-1658. https://doi.org/10.5194/amt-6-1647-2013

Klemm, O. and Lin, N.H. (2016). What causes observed fog trends: Air quality or climate change? Aerosol Air Qual. Res. 16: 1131-1142. https://doi.org/10.4209/aaqr.2015.0 5.0353

Kulshrestha, M.J., Kulshrestha, U.C., Parashar, D.C. and Vairamani, M. (2003). Estimation of $\mathrm{SO}_{4}$ contribution by dry deposition of $\mathrm{SO}_{2}$ onto the dust particles in India. Atmos. Environ. 37: 3057-3063. https://doi.org/10.1016/ S1352-2310(03)00290-5

Kulshrestha, U.C., Nageswara Rao, T., Azhaguvel, S. and Kulshrestha, M.J. (2004). Emissions and accumulation of metals in the atmosphere due to crackers and sparkles during Diwali festival in India. Atmos. Environ. 38: 4421-4425. https://doi.org/10.1016/j.atmosenv.2004.05. 044

Kulshrestha, M.J., Sekar, R., Krishna, D., Hazarika, A.K., Dey, N.C. and Rao, P.G. (2005). Deposition fluxes of chemical components of fog water at a rural site in north- east India. Tellus B 57: 436-439. https://doi.org/10.3402 /tellusb.v57i5.16566

Kulshrestha, U.C. and Sharma, D. (2015). Importance of atmospheric dust in India: Future scope of research. $J$. Indian Geophys. Union 19: 205-209.

Kumar, B., Singh, S., Gupta, G.P., Lone, F.A. and Kulshrestha, U.C. (2016). Long range transport and wet deposition fluxes of major chemical species in snow at Gulmarg in North Western Himalayas (India). Aerosol Air Qual. Res. 16: 606-617. https://doi.org/10.4209/aaqr. 2015.01.0056

Lee, Y.N., Weber, R., Ma, Y., Orsini, D., Maxwell-Meier, K., Blake, D., Meinardi, S., Sachse, G., Harward, C., Chen, T.Y., Thornton, D., Tu, F.H. and Bandy, A. (2003). Airborne measurement of inorganic ionic components of fine aerosol particles using the particle-into-liquid sampler coupled to ion chromatography technique during ACE-Asia and TRACE-P. J. Geophys. Res. 108: 8646. https://doi.org/10.1029/2002JD003265

Lekouch, I., Mileta, M., Muselli, M., MilimoukMelnytchouk, I., Šojat, V., Kabbachi, B. and Beysens, D. (2010). Comparative chemical analysis of dew and rain water. Atmos. Res. 95: 224-234. https://doi.org/10.1016/ j.atmosres.2009.10.002

Liu, T., Marlier, M.E., DeFries, R.S., Westervelt, D.M., Xia, K.R., Fiore, A.M., Mickley, L.J., Cusworth, D.H. and Milly, G. (2018). Seasonal impact of regional outdoor biomass burning on air pollution in three Indian cities: Delhi, Bengaluru, and Pune. Atmos. Environ. 172: 83-92. https://doi.org/10.1016/j.atmosenv.2017.10.024

Lopez-Hilfiker, F.D., Mohr, C., Ehn, M., Rubach, F., Kleist, E., Wildt, J., Mentel, T.F., Lutz, A., Hallquist, M., Worsnop, D. and Thornton, J.A. (2014). A novel method for online analysis of gas and particle composition: description and evaluation of a Filter Inlet for Gases and AEROsols (FIGAERO). Atmos. Meas. Tech. 7: 9831001. https://doi.org/10.5194/amt-7-983-2014

Mishra, M. and Kulshrestha, U. (2017). Chemical characteristics and deposition fluxes of dust-carbon mixed coarse aerosols at three sites of Delhi, NCR. $J$. Atmos. Chem. 74: 399-421. https://doi.org/10.1007/s108 74-016-9349-1

Morgan, J.J. (1982). Factors governing the pH, availability of $\mathrm{H}^{+}$, and oxidation capacity of rain. In Atmospheric Chemistry, Goldberg, E.D. (Ed.), Springer Berlin Heidelberg, pp. 17-40. https://doi.org/10.1007/978-3642-68638-2_3

Mu, L., Zheng, L., Liang, M., Tian, M., Li, X. and Jing, D. (2019). Characterization and source analysis of watersoluble ions in atmospheric particles in Jinzhong, China. Aerosol Air Qual. Res. 19: 2396-2409. https://doi.org/10. 4209/aaqr.2019.03.0109

Nair, V.S., Moorthy, K.K., Alappattu, D.P., Kunhikrishnan, P.K., George, S., Nair, P.R., Babu, S.S., Abish, B., Satheesh, S.K., Tripathi, S.N., Niranjan, K., Madhavan, B.L., Srikant, V., Dutt, C.B.S., Badarinath, K.V.S. and Reddy, R.R. (2007). Wintertime aerosol characteristics over the Indo-Gangetic Plain (IGP): Impacts of local boundary layer processes and long-range transport. $J$. 
Geophys. Res. 112: D13205. https://doi.org/10.1029/200 6JD008099

Nakajima, T., Yoon, S.C., Ramanathan, V., Shi, G.Y., Takemura, T., Higurashi, A., Takamura, T., Aoki, K., Sohn, B.J., Kim, S.W., Tsuruta, H., Sugimoto, N., Shimizu, A., Tanimoto, H., Sawa, Y., Lin, N.H., Lee, C.T., Goto, D. and Schutgens, N. (2007). Overview of the Atmospheric Brown Cloud East Asian Regional Experiment 2005 and a study of the aerosol direct radiative forcing in east Asia. J. Geophys. Res. 112: D24S91. https://doi.org/10.1029/2007JD009009

Nath, S. and Yadav, S. (2018). A comparative study on fog and dew water chemistry at New Delhi, India. Aerosol Air Qual. Res. 18: 26-36. https://doi.org/10.4209/aaqr.2017.01.0033

Pan, X., Chin, M., Gautam, R., Bian, H., Kim, D., Colarco, P.R., Diehl, T.L., Takemura, T., Pozzoli, L., Tsigaridis, K., Bauer, S. and Bellouin, N. (2015). A multi-model evaluation of aerosols over South Asia: common problems and possible causes. Atmos. Chem. Phys. 15: 5903-5928. https://doi.org/10.5194/acp-15-5903-2015

Pani, S.K. and Verma, S. (2014). Variability of winter and summertime aerosols over eastern India urban environment. Atmos. Res. 137: 112-124. https://doi.org/10.1016/j.atmo sres.2013.09.014

Pani, S.K., Lee, C. Te, Chou, C.C.K., Shimada, K., Hatakeyama, S., Takami, A., Wang, S.H. and Lin, N.H. (2017). Chemical characterization of wintertime aerosols over Islands and mountains in East Asia: Impacts of the continental Asian outflow. Aerosol Air Qual. Res. 17: 3006-3036. https://doi.org/10.4209/aaqr.2017.03.0097

Perrino, C., Tiwari, S., Catrambone, M., Torre, S.D., Rantica, E. and Canepari, S. (2011). Chemical characterization of atmospheric PM in Delhi, India, during different periods of the year including Diwali festival. Atmos. Pollut. Res. 2: 418-427. https://doi.org/10.5094/APR.2011.048

Prakash Gupta, G., Kumar, B., Singh, S. and Kulshrestha, C. (2016). Deposition and impact of urban atmospheric dust on two medicinal plants during different seasons in NCR Delhi. Aerosol Air Qual. Res. 16: 2920-2932. https://doi.org/10.4209/aaqr.2015.04.0272

Raes, F., Van Dingenen, R., Vignati, E., Wilson, J., Putaud, J.P., Seinfeld, J.H. and Adams, P. (2000). Formation and cycling of aerosols in the global troposphere. Atmos. Environ. 34: 4215-4240. https://doi.org/10.1016/S13522310(00)00239-9

Rajput, P. (2018). OM/OC ratio of polar and non-polar organic matter during wintertime from Indo-Gangetic Plain: Implications to regional-scale radiative forcing. Aerosol Sci. Eng. 2: 153-164. https://doi.org/10.1007/s4 1810-018-0032-6

Rajput, P., Gupta, T. and Kumar, A. (2016). The diurnal variability of sulfate and nitrate aerosols during wintertime in the Indo-Gangetic Plain: Implications for heterogeneous phase chemistry. RSC Adv. 6: 8987989887. https://doi.org/10.1039/C6RA19595D

Rajput, P., Singh, D.K., Singh, A.K. and Gupta, T. (2018). Chemical composition and source-apportionment of submicron particles during wintertime over Northern India: New insights on influence of fog-processing. Environ.
Pollut. 233: 81-91. https://doi.org/10.1016/j.envpol.2017. 10.036

Ram, K., Sarin, M.M., Sudheer, A.K. and Rengarajan, R. (2012). Carbonaceous and secondary inorganic aerosols during wintertime fog and haze over urban sites in the Indo-Gangetic plain. Aerosol Air Qual. Res. 12: 355-366. https://doi.org/10.4209/aaqr.2011.07.0105

Ramanathan, V., Chung, C., Kim, D., Bettge, T., Buja, L., Kiehl, J.T., Washington, W.M., Fu, Q., Sikka, D.R. and Wild, M. (2005). Atmospheric brown clouds: Impacts on South Asian climate and hydrological cycle. Proc. Natl. Acad. Sci. U.S.A. 102: 5326-5333. https://doi.org/10.10 73/pnas.050065610

Rao, G. and Vejerano, E.P. (2018). Partitioning of volatile organic compounds to aerosols: A review. Chemosphere 212: 282-296. https://doi.org/10.1016/j.chemosphere.20 18.08 .073

Satyanarayana, J., Reddy, L.A.K., Kulshrestha, M.J., Rao, R.N. and Kulshrestha, U.C. (2010). Chemical composition of rain water and influence of airmass trajectories at a rural site in an ecological sensitive area of Western Ghats (India). J. Atmos. Chem. 66: 101-116. https://doi.org/10.1 007/s10874-011-9193-2

Seaton, A., Godden, D., MacNee, W. and Donaldson, K. (1995). Particulate air pollution and acute health effects. Lancet 345: 176-178. https://doi.org/10.1016/S01406736(95)90173-6

Seinfeld, J.H. and Pandis, S.N. (1998). Atmospheric chemistry and physics: From air pollution to climate change, Wiley.

Sen, A., Abdelmaksoud, A.S., Nazeer Ahammed, Y., Alghamdi, M.A., Banerjee, T., Bhat, M.A., Chatterjee, A., Choudhuri, A.K., Das, T., Dhir, A., Dhyani, P.P., Gadi, R., Ghosh, S., Kumar, K., Khan, A.H., Khoder, M., Maharaj Kumari, K., Kuniyal, J.C., Kumar, M., ... Mandal, T.K. (2017). Variations in particulate matter over Indo-Gangetic Plains and Indo-Himalayan Range during four field campaigns in winter monsoon and summer monsoon: Role of pollution pathways. Atmos. Environ. 154: 200-224. https://doi.org/10.1016/j.atmose nv.2016.12.054

Shi, Q., Davidovits, P., Jayne, J.T., Worsnop, D.R. and Kolb, C.E. (1999). Uptake of gas-phase ammonia. 1. Uptake by aqueous surfaces as a function of pH. J. Phys. Chem. A. 103: 8812-8823. https://doi.org/10.1021/jp991696p

Singh, D.P., Gadi, R., Mandal, T.K., Dixit, C.K., Singh, K., Saud, T., Singh, N. and Gupta, P.K. (2010). Study of temporal variation in ambient air quality during Diwali festival in India. Environ. Monit. Assess. 169: 1-13. https://doi.org/10.1007/s10661-009-1145-9

Singh, R.P. and Kaskaoutis, D.G. (2014). Crop residue burning: A threat to south Asian air quality. Eos 95: 333334. https://doi.org/10.1002/2014EO370001

Singh, R., Kulshrestha, M.J., Kumar, B. and Chandra, S. (2016). Impact of anthropogenic emissions and open biomass burning on carbonaceous aerosols in urban and rural environments of Indo-Gangetic Plain. Air Qual. Atmos. Health 9: 809-822. https://doi.org/10.1007/s1186 9-015-0377-9 
Singh, S. and Kulshrestha, U.C. (2014). Rural versus urban gaseous inorganic reactive nitrogen in the Indo-Gangetic plains (IGP) of India. Environ. Res. Lett. 9. https://doi.org /10.1088/1748-9326/9/12/125004

Singh, S., Gupta, G.P., Kumar, B. and Kulshrestha, U.C. (2014). Comparative study of indoor air pollution using traditional and improved cooking stoves in rural households of Northern India. Energy Sustainable Dev. 19: 1-6. https://doi.org/10.1016/j.esd.2014.01.007

Spaulding, R.S., Talbot, R.W. and Charles, M.J. (2002). Optimization of a mist chamber (cofer scrubber) for sampling water-soluble organics in air. Environ. Sci. Technol. 36: 1798-1808. https://doi.org/10.1021/es0111 $89 \mathrm{x}$

Stratton, W.J., Lindberg, S.E. and Perry, C.J. (2001). Atmospheric mercury speciation: Laboratory and field evaluation of a mist chamber method for measuring reactive gaseous mercury. Environ. Sci. Technol. 35: 170-177. https://doi.org/10.1021/es001260j

Straub, D.J., Hutchings, J.W. and Herckes, P. (2012). Measurements of fog composition at a rural site. Atmos. Environ. 47: 195-205. https://doi.org/10.1016/j.atmosen v.2011.11.014

Tie, X., Huang, R.J., Cao, J., Zhang, Q., Cheng, Y., Su, H., Chang, D., Pöschl, U., Hoffmann, T., Dusek, U., Li, G., Worsnop, D.R. and O'Dowd, C.D. (2017). Severe pollution in China amplified by atmospheric moisture. Sci. Rep. 7: 15760. https://doi.org/10.1038/s41598-01715909-1

Tiwari, R., Gupta, G.P. and Kulshrestha, U.C. (2016). Summer time dustfall fluxes of reactive nitrogen and other inorganic species over the tropical megacity of Indo-Gangetic Plains. Earth Interact. 20: 1-20. https://doi.org/10.1175/EI-D-15-0053.1

Tiwari, S., Chate, D.M., Bisht, D.S., Srivastava, M.K. and Padmanabhamurty, B. (2012). Rainwater chemistry in the North Western Himalayan Region, India. Atmos. Res. 104-105: 128-138. https://doi.org/10.1016/j.atmosres.20 11.09 .006

Trebs, I., Metzger, S., Meixner, F.X., Helas, G., Hoffer, A.,
Rudich, Y., Falkovich, A.H., Moura, M.A.L., Da Silva, R.S., Artaxo, P., Slanina, J. and Andreae, M.O. (2005). The $\mathrm{NH}_{4}{ }^{+}-\mathrm{NO}_{3}{ }^{-}-\mathrm{Cr}-\mathrm{SO}_{4}{ }^{2-}-\mathrm{H}_{2} \mathrm{O}$ aerosol system and its gas phase precursors at a pasture site in the Amazon Basin: How relevant are mineral cations and soluble organic acids? J. Geophys. Res. 110: 1-18. https://doi.org/10.102 9/2004JD005478

Verma, N., Satsangi, A., Lakhani, A. and Kumari, K.M. (2017). Low molecular weight monocarboxylic acids in $\mathrm{PM}_{2.5}$ and $\mathrm{PM}_{10}$ : Quantification, seasonal variation and source apportionment. Aerosol Air Qual. Res. 17: 485498. https://doi.org/10.4209/aaqr.2016.05.0183

Waldman, J.M., Munger, J.W., Jacob, D.J., Flagan, R.C., Morgan, J.J. and Hoffmann, M.R. (1982). Chemical composition of acid fog. Science 218: 677-680. https://doi.org/10.1126/science.218.4573.677

Wang, H., Xu, J., Zhang, M., Yang, Y., Shen, X., Wang, Y., Chen, D. and Guo, J. (2014). A study of the meteorological causes of a prolonged and severe haze episode in January 2013 over central-eastern China. Atmos. Environ. 98: 146157. https://doi.org/10.1016/j.atmosenv.2014.08.053

Wang, Y., Zhuang, G., Tang, A., Yuan, H., Sun, Y., Chen, S. and Zheng, A. (2005). The ion chemistry and the source of $\mathrm{PM}_{2.5}$ aerosol in Beijing. Atmos. Environ. 39:37713784. https://doi.org/10.1016/j.atmosenv.2005.03.013

Xu, Y., Xue, W., Lei, Y., Zhao, Y., Cheng, S., Ren, Z. and Huang, Q. (2018). Impact of meteorological conditions on $\mathrm{PM}_{2.5}$ pollution in China during winter. Atmosphere 9: 429. https://doi.org/10.3390/atmos9110429

Zhang, Y., Chen, Y., Meng, A., Li, Q. and Cheng, H. (2008). Experimental and thermodynamic investigation on transfer of cadmium influenced by sulfur and chlorine during municipal solid waste (MSW) incineration. J. Hazard. Mater. 153: 309-319. https://doi.org/10.1016/j.jhazmat. 2007.08.054

Received for review, January 19, 2020

Revised, April 8, 2020

Accepted, April 25, 2020 